Prawo Kanoniczne 58 (2015) nr 2

KS. JANUSZ GRĘŹLIKOWSKI

Wydział Prawa Kanonicznego

Uniwersytetu Kardynała Stefana Wyszyńskiego

\title{
ODNOWA DUSZPASTERSKA W DIECEZJI \\ WŁOCŁAWSKIEJ W ŚWIETLE UCHWAŁ \\ SYNODÓW BISKUPA STANISŁAWA \\ KARNKOWSKIEGO Z 1568 I 1579 ROKU
}

Treść: Wstęp. - 1. Osoba biskupa Stanisława Karnkowskiego. - 2. Synody włocławskie biskupa Karnkowskiego narzędziem reformy trydenckiej. - 2.1. Synod z 1568 roku. - 2.2. Synod z 1579 roku. - 3. Reaktywowanie i reorganizacja struktur administracyjnych diecezji. - 4. Powołanie do życia seminarium duchownego. - 5. Obowiązki i zadania duszpasterskie proboszczów. -6 . Przekaz wiary i nauczanie. -7 . Sprawowanie i przyjmowanie sakramentów św. - 8. Pozostałe akty kultu Bożego, miejsca i czasy święte oraz sprawy liturgiczne. - Zakończenie.

\section{Wstęp}

W historyczno-prawnej refleksji nad rolą i znaczeniem polskiego ustawodawstwa partykularnego, które w dużej mierze kształtowało i kształtuje obraz i życie Kościoła w Polsce znaczące miejsce posiada Sobór Trydencki (1545-1563), który w historii Kościoła, diecezji włocławskiej i prawa kanonicznego uznawany jest za punkt zwrotny początkujący wielką i potrzebną reformę, która owocowała prawie do początku XX wieku. Zainicjowane przez Tridentinum dzieło reformy i odnowy Kościoła w Polsce stanowiło złożony i długotrwały proces wymagający od biskupów polskich wielkiego wysiłku i trudu wprowadzenia go w życie Kościołów lokalnych. Wielu biskupów polskich z drugiej połowy XVI i XVII wieku odegrało ważną i znaczącą rolę 
w potrydenckiej odnowie i reformie Kościoła polskiego, bowiem to od osoby stojącego na czele diecezji w pierwszym rzędzie zależał proces przyswajania osiągnięć Tridentinum. Dzięki ich wysiłkom ustawodawczym i organizacyjno-duszpasterskim proces recepcji dekretów Soboru Trydenckiego znalazł doskonałe warunki do dalszego rozwoju ${ }^{1}$.

Pierwszym biskupem włocławskim, wtedy kujawsko-pomorskim², który podjął dzieło potrydenckiej odnowy diecezji był Stanisław Karnkowski (1567-1581) - rzecznik wprowadzenia w życie diecezji natychmiastowej reformy trydenckiej, wybitny ustawodawca, reformator, wyrosły i uformowany w atmosferze Soboru Trydenckiego, a późniejszy arcybiskup gnieźnieński i prymas Polski (1582-1603) ${ }^{3}$. Zgodnie z zamierzeniem Trydentu, biskup Karnkowski podjął energiczną i zdecydowaną próbę odnowy diecezji na wielu odcinkach życia religijno-moralnego odbywając w tym celu dwa synody: w 1568 i 1579 r., a także podejmując inne działania prawno-duszpasterskie. Właśnie w nich zogniskowała się działalność reformatorska,

\footnotetext{
${ }^{1}$ W. GórAlski, Andrzej Chryzostom Załuski biskup płocki 1692-1698. Wkład $w$ dzieło recepcji reformy trydenckiej, Warszawa 1987, s. 5; zob. J. KŁoczowsKI, Uwagi wstępne. Chrześcijaństwo polskie XVI-XVIII wieku, w: Kościół w Polsce, t. II, Kraków 1969, s. 39-53.

${ }^{2}$ Od początku XII wieku obecną diecezję włocławską nazywano kujawską. Na synodzie prowincjonalnym piotrkowskim w $1551 \mathrm{r}$. nakazano biskupom tytułować się biskup włocławski i Pomorza. Odtąd, aż do początków XIX stulecia diecezja nosiła nazwę Vladislaviensis et Pomeraniae. W języku polskim nie używano nazwy diecezja włocławsko-pomorska, czy włocławska i pomorska, ale kujawsko-pomorska lub poprawniej kujawska i pomorska. Bogata i trudna historia diecezji włocławskiej obejmuje cztery zasadnicze okresy: kruszwicki (od początków do 1123 r.), kujawsko pomorski (1123 - 1818), kujawsko - kaliski (1818 - 1925) i włocławski (od 1925 r. Zob. Rocznik Diecezji Włocławskiej, Włocławek 1991, s. 31-33; S. Librowski, Wizytacje diecezji włocławskiej, Archiwa Biblioteki i Muzea Kościelne 8(1964) cz. I, t. 1, z. 1, s. 29.

${ }^{3}$ Zob. J. GręźLikowsKi, Wkład biskupa Stanisława Karnkowskiego w dzieło recepcji reformy trydenckiej $w$ diecezji włocławskiej, Prawo Kanoniczne 44(2001) nr 1-2, s. 161-184. Por. M. Kosman, Między oltarzem a tronem. Poczet prymasów Polski, Poznań 2000, s. 135-141.
} 
zorientowanego m.in. ku odnowie duszpasterstwa, troskliwego rządcy diecezji. Odnosiła się ona głównie do reaktywowania i reorganizacji struktur administracyjnych diecezji, określenia obowiązków i zadań duszpasterskich proboszczów, przekazu wiary i nauczania, sprawowania i przyjmowania sakramentów, jak i spraw liturgicznych.

\section{Osoba biskupa Stanisława Karnkowskiego}

Stanisław Karnkowski urodził się 10 maja 1520 r. w Karnkowie w ziemi dobrzyńskiej i pochodził ze starej rodziny herbu Junosza. Jako młodzieniec opuścił dom rodzinny i udał się do swego stryja biskupa Włocławskiego Jana Karnkowskiego, który kierował diecezją kujawsko-pomorską w latach 1531- 1538. Jemu to Karnkowski zawdzięcza swoje wykształcenie, bowiem majątek jaki posiadali Karnkowscy nie wystarczyłby na gruntowne i wysokie wykształcenie ${ }^{4}$. Na skutek choroby swego stryja - biskupa, Karnkowski podejmuje studia dopiero po śmierci swego opiekuna, który umiera w grudniu 1537 r. Najpierw studiował od 1539 do 1545 r. na Akademii Krakowskiej, a potem za granicą w Perugii i Padwie, gdzie zakończył swoje studia uzyskaniem doktoratu utriusque iuris ${ }^{5}$. Wracając do kraju na jakiś okres zatrzymał się w Niemczech - w Wittenberdze - gdzie zapoznał się z nauką Lutra, czego wynikiem było jego odejście od Kościoła $^{6}$. Po powrocie ze studiów w 1550 r. został sekretarzem biskupa chełmińskiego, a później włocławskiego Jana Drohojowskiego (15511557), a potem w roku 1553 został notariuszem publicznym. W roku 1555 został przyjęty na dwór króla Zygmunta Augusta jako jeden z sekretarzy królewskich. Był to czas największej świetności dworu

\footnotetext{
${ }^{4} \mathrm{~J}$. Korytкowski, Arcybiskupi gnieźnieńscy, prymasowie i metropolici polscy od roku 1000 aż do końca 1821 r., t. III, Poznań 1889, s. 422-423; Zob. H. KowalsKa, Karnkowski Stanisław, w: Polski Słownik Biograficzny, pod red. A. Romiszowskiego i J. Rudowskiego, t. XII, Kraków 1935, s. 77.

${ }^{5}$ E. OzonowsKI, Karnkowski Stanisław. Słownik polskich teologów katolickich (pod red. H. E. Wyczawskiego), t. II, Warszawa 1982, s. 263-264.

${ }^{6}$ S. KęTrZyŃski, Karnkowski Stanisław. Podręczna Encyklopedia Kościelna (pod red. Z. Chełmickiego), t. XIX-XX, Warszawa 1910, s. 354.
} 
królewskiego, związany z humanizmem ${ }^{7}$. Pobyt na dworze wywarł na Karnkowskim decydujące znaczenie, w tym także ustaliły się i wykrystalizowały jego poglądy, tym razem zgodne z nauką Kościoła. Od podjęcia pracy na dworze królewskim, Karnkowski utrzymuje kontakty listowne $\mathrm{z}$ biskupem warmińskim Hozjuszem. W roku 1558 został mianowany kanonikiem kolegiaty wieluńskiej, a także kanonikiem kapituły gnieźnieńskiej. ${ }^{8}$ W roku 1560 zostaje przyjęty jako koadiutor kanonika Dąbrowskiego do kapituły krakowskiej, która w tym czasie uważana była za seminarium dla przyszłych biskupów, a obok uniwersytetu stanowiła najsilniejszy ośrodek walki z reformacją ${ }^{9}$. W dwa lata później - w 1562 r. - został Karnkowski kanonikiem kolegiaty warszawskiej, ale po pół roku zrezygnował z niej ${ }^{10}$.

W roku 1564, a więc w 44-tym roku życia, w wigilię Bożego Narodzenia, przyjmuje święcenia kapłańskie z rąk biskupa teodozjeńskiego Stanisława Falęckiego, sufragana i kanonika gnieźnieńskiego, opata sulejowskiego i Ojca Soboru Trydenckiego ${ }^{11}$. Biskup Falęcki wyświęcił Karnkowskiego - kleryka diecezji płockiej - za zgodą jego ordynariusza w swoim kościele opackim ${ }^{12}$. Biografowie Karnkowskiego podają, że ostateczną decyzję o przyjęciu święceń przyjął on pod wpływem rady swego przyjaciela - biskupa Hozjusza i nuncjusza papieskiego G. F. Commendoniego ${ }^{13}$.

23 czerwca 1567 r. król Zygmunt August pisze list do papieża o zatwierdzenie ks. Stanisława Karnkowskiego na biskupa kujawsko-pomorskiego, w którym stwierdza, że kandydat jest nobilissimis domi suae procreatus parentibus, a także przedstawiając opłakany stan diecezji włocławskiej, który może uleczyć proponowany kandydat,

\footnotetext{
${ }^{7}$ H. KowalsKa, Karnkowski Stanisław..., s. 77.

${ }^{8}$ J. Kory tкowski, Arcybiskupi gnieźnieńscy..., t. III, s. 423.

${ }^{9}$ L. ŁĘTOwsKi, Katalog biskupów, prałatów i kanoników krakowskich, t. III, Kraków 1852, s. 108.

${ }^{10}$ A. Chmielowski, Życiorys księdza Stanisława Karnkowskiego arcybiskupa gnieźnieńskiego, Warszawa 1884, s. 3.

${ }^{11}$ Tamże, s. 86-88.

${ }^{12}$ J. Kory tкоwski, Arcybiskupi gnieźnieńscy..., t. III, s. 424.

${ }^{13}$ Tamże.
} 
„najbardziej właściwy ze względu na odpowiednie na tej funkcji cnoty i pobożność"14. Biskupem kujawsko-pomorskim czyli włocławskim został mianowany po zmarłym biskupie Mikołaju Wolskim (1562-1567) 1 października 1567 r., a wyświęconym na biskupa został na początku stycznia $1568 \mathrm{r}$. Biskupem włocławskim był do roku 1581, po czym przeszedł na stolicę gnieźnieńską ${ }^{15}$. Kierował diecezją włocławską przez czternaście lat przyczyniając się do jej odrodzenia religijno-moralnego i rozkwitu przez swoją pełną troski i gorliwości działalność na polu ustawodawczym, reformatorskim i duszpasterskim. Działalność Karnkowskiego jako biskupa włocławskiego sprawiła, że cieszył się w Kościele polskim większą powagą aniżeli ówczesny prymas Jakub Uchański. Wynikało to zapewne z faktu, iż w okresie reformistycznych osiągnięć trydenckich, biskup Karnkowski należał do najwybitniejszych biskupów polskich. Zasłynął jako oddany reformator Kościoła katolickiego, obrońca wiary i Kościoła przed nasilającą się falą protestantyzmu, krzewiciel oświaty, reformator obyczajów duchowieństwa i wiernych świeckich ${ }^{16}$. Jeszcze za życia tego ostatniego przewidywano, że Karnkowski zajmie jego miejsce. I rzeczywiście tak się stało. W 1581 r. biskup Stanisław Karnkowski został arcybiskupem gnieźnieńskim i prymasem Polski. Jako arcybiskup gnieźnieński przewodniczył trzem synodom diecezjalnym i jednemu prowincjalnemu w Piotrkowie w roku 1589. Założył seminarium duchowne we Włocławku w 1569 r. - jako biskup włocławski, a jako metropolita gnieźnieńskie w Kaliszu w 1593 r. oraz w Gnieźnie w roku 1601. Tym samym w sposób znaczący przyczynił się do rozwoju kształcenia duchowieństwa i podniesienia jego dyscypliny i obyczajów, jak też dbał o właściwe przygotowanie duchowe i intelektualne adeptów do kapłaństwa. Wspierał też znakomicie tłumaczenie Biblii przez jezuitę Jakuba Wujka. Ostatnie dni życia spędził w Łowiczu

\footnotetext{
${ }^{14}$ Tamże, s. 425.

${ }^{15}$ Tamże, s. 421-432; W. Kujawski, Pasterz Kościoła okresu potrydenckiego, Ład Boży 12(1988) s. 6.

${ }^{16}$ S. Tymosz, Zbiór biskupa Stanisława Karnkowskiego z 1579 roku, Roczniki Nauk Prawnych 13 (2003) z. 2, s. 55.
} 
w tamtejszym klasztorze bernardynów, gdzie zmarł 8 czerwca 1603 r., po skończeniu 83 lat. Pochowany został w ufundowanym przez siebie kościele jezuitów w Kaliszu ${ }^{17}$.

\section{Synody włocławskie biskupa Karnkowskiego narzędziem reformy trydenckiej}

Sobór Trydencki wyraźnie wskazał, że podstawowym narzędziem realizacji reformy trydenckiej na szczeblu diecezjalnym mają być synody diecezjalne. W myśl postanowień Soboru synody te miały odbywać się co roku ${ }^{18}$. W Kościele polskim respektowanie tego przepisu napotykało na wiele trudności. Stąd też synod prowincjalny piotrkowski z 1589 r. złagodził ten obowiązek, ustalając, że synody diecezjalne odbywać się będą co trzy lata. W rzeczywistości i ta norma nie była przestrzegana ${ }^{19}$. Niewątpliwie musiała istnieć na to zgoda Stolicy Apostolskiej, jeśli nie wyraźna to przynajmniej milcząca, skoro nawet najgorliwsi polscy biskupi rzadziej zwoływali synod niż wymagało tego prawo i nie stosowano kar wobec biskupów zaniedbujących tego obowiązku ${ }^{20}$.

W czasie gdy kończyły się obrady Soboru i po jego zakończeniu we Włocławku rządził podeszły wiekiem i przez to mniej ruchliwy biskup Mikołaj Wolski (1562-1567). Dekrety trydenckie przeszły tu bez większego echa. Biskup Karnkowski obejmując diecezję w 1567 r., starał się to opóźnienie nadrobić ${ }^{21}$. Zdawał sobie bowiem sprawę, że

\footnotetext{
${ }^{17}$ J. Umińsкi, Historia Kościoła, t. II, Opole 1960, s. 169-171; W. KuJAwski, Pasterz Kościoła..., s. 6.

${ }^{18}$ Conc. Trid., sess. XXIV, c. 2 de ref.

${ }^{19}$ M. MorawsKi, Synod diecezjalny $w$ dawnej Polsce, Włocławek 1937, s. 7-8.

${ }^{20}$ A. Petrani, Kanonistyka, w: Dzieje teologii katolickiej w Polsce (pod red. M. Rechowicza), t. I - Średniowiecze, Lublin 1974, s. 388-389.

${ }^{21} \mathrm{~W}$ trakcie obrad Soboru Trydenckiego w diecezji włocławskiej odbyły się cztery synody: trzy zwołał biskup Andrzej Zebrzydowski (1546-1551) - dwa cząstkowe w 1547 i 1550 r. oraz diecezjalny w 1551 r., jeden odbył biskup Jan Drohohojewski (1551-1557) w 1554 r., które jednak nie podjęły sprawy reform. Nie znamy uchwał tych synodów, gdyż nie zachowały się ich statuty i dlatego trudno jednoznacznie ocenić ich charakter i znaczenie. Zob. Z. ChODYŃski, Statuta synodalia dioecesis
} 
ze względu na swe położenie i uwarunkowania społeczno-ekonomiczne diecezja była szczególnie narażona na wpływy reformacji. Stąd od samego początku swoich rządów diecezją podjął energiczną próbę odnowy Kościoła włocławskiego na wielu odcinkach jego życia religijno-moralnego i duszpasterskiego odbywając w tym celu między innymi dwa synody diecezjalne. Ŝwiadom, że realizacja reformy trydenckiej na szczeblu diecezjalnym zależy od jego osobistego zaangażowania się $\mathrm{w}$ proces odnowy duszpasterstwa, jego działania prawno-administracyjne stały się ważnym narzędziem kształtowania nowej rzeczywistości prawnej i duszpasterskiej w diecezji włocławskiej doby potrydenckiej.

\subsection{Synod z 1568 roku}

Wkrótce po objęciu stolicy biskupiej biskup Karnkowski dostrzegając głęboki kryzys w duszpasterstwie oraz zaniedbania w życiu religijno-moralnym duchowieństwa i wiernych, energicznie zabrał się do odnowy i reformy powierzonej mu diecezji. Działania te podjął poprzez zwołanie w pół roku po rozpoczęciu rządów diecezją. Otóż dnia 14 lutego $1568 \mathrm{r}$. wydał dekret - mandatum zwołujący synod diecezjalny do Włocławka ad diem Martis, alies feriam tertiam post Dominicam "Reminiscere" proximam, czyli na 16 marca 1568 r. Należy zauważyć, że synod ten został zwołany dziewięć lat wcześniej od oficjalnego przyjęcia przez Kościół w Polsce na synodzie prowincjalnym w 1577 r. uchwał soborowych ${ }^{22}$. Stąd temu gorącemu rzecznikowi odnowy trydenckiej, reformatorowi i niezmordowanemu w swoich przedsięwzięciach ustawodawcy i pasterzowi, diecezja włocławska zawdzięcza rozpoczęcie procesu recepcji reformy trydenckiej i odnowy duszpasterstwa, co łączyło się również z podjęciem działań

Wladislaviensis et Pomeraniae, Vladislaviae 1890, s. XXVII, XXVIII; S. LIBrowsKI, Synody diecezji włocławskiej, Kronika Diecezji Włocławskiej 50(1967) s. 87.

${ }^{22}$ Zob. T. Glemma, M. Banaszak, Przyjęcie reformy trydenckiej $w$ Kościele polskim, w: Historia Kościoła w Polsce (pod red. B. Kumora, Z. Obertyńskiego) t. I, cz. 2, Poznań-Warszawa 1974, s. 173-207; P. Aleksandrowicz, Przyjęcie przez króla i senat uchwat Soboru Trydenckiego w Parczewie w 1564 r., Prawo Kanoniczne 9(1966) nr 3-4, s. 363-381. 
zmierzających do dostosowania prawa diecezjalnego do nowego ustawodawstwa powszechnego. Znając reformistyczne dekrety soborowe, pragnął być biskupem na miarę postanowień tego Soboru, podejmując energiczną próbę odnowy diecezji na wielu odcinkach jej życia religijno-moralnego i duszpasterskiego.

Głównym celem pierwszego potrydenckiego synodu diecezjalnego, obradującego w dniach 16 i 17 maja 1568 r., było przedstawienie uchwał i dekretów soborowych, ich oficjalne przyjęcie przez diecezję kujawsko-pomorską, czyli włocławską oraz wprowadzenie ich w życie diecezji, co również odnosiło się do odnowienia i ożywienia duszpasterstwa. Owocem obrad synodalnych było 26 zatytułowanych artykułów podzielonych na trzy nie zatytułowane części ${ }^{23}$. Część pierwsza zawierała wskazania do kogo i w jakim celu uchwalono konstytucje synodalne. Była ugruntowaniem i przekazaniem prawowiernej nauki Kościoła oraz wyjaśnieniem dla duchowieństwa zasad postępowania i życia zgodnego z zasadami prawa trydenckiego. Wzywała do karności i dyscypliny duchowieństwo, zobowiązywała do strzeżenia dóbr kościelnych i właściwego nimi administrowania. Sporo miejsca poświęcił biskup Karnkowski sprawom przygotowania kandydatów do kapłaństwa. Ogłosił zamiar powołania szkoły kształcącej i wychowującej przyszłych kapłanów (seminarium). Określił a jakich funduszy będzie się ona utrzymywała. Akt ten stanowi fundację seminarium duchownego we Włocławku, które w sposób kanoniczny zostało erygowane 16 sierpnia $1569 \mathrm{r}^{24}$ Wprowadził jasne przepisy co do beneficjów kościelnych i symonii. Szczegółowo i precyzyjnie określił prawa i obowiązki proboszczów, wikariuszy, zakonników i tych wszystkich, którzy zajmowali się duszpasterstwem ${ }^{25}$.

Druga część dokumentu synodalnego została poświęcona omówieniu niektórych sakramentów i sakramentaliów. Najpierw uchwały

\footnotetext{
${ }^{23}$ Acta synodi dioecesanae Wladislaviae Anno 1568 per Stanislaum Karnkowski episcopum celebratae, Z. CHody ŃsKi, Statuta synodalia..., s. 50-70.

${ }^{24}$ W. Kujawski, Pasterz Kościoła..., s. 6.

${ }^{25}$ Por. J. Gręźlıkowski, Recepcja reformy trydenckiej $w$ diecezji włocławskiej $w$ świetle ustawodawstwa synodalnego, Włocławek 2000, s. 143-144.
} 
synodu precyzyjnie podawały i wyjaśniały przepisy odnośnie chrztu, potem Eucharystii, sakramentu pokuty i namaszczenia chorych. Bardzo wnikliwie przedstawione zostały przepisy co do sakramentu małżeństwa, a szczególnie co do formy jego zawarcia. Końcowe statuty drugiej części uchwał synodalnych podejmowały temat sakramentaliów ${ }^{26}$.

Ostatnia część dokumentu synodalnego poświęcona została przez prawodawcę obowiązkom duchowieństwa i dyscyplinie kościelnej oraz życiu chrześcijańskiemu w różnych jego przejawach. Biskup wzywał kapłanów do życia świętego, zgodnego $\mathrm{z}$ ich powołaniem, wyjaśniał zadania spowiedników i kaznodziejów, zobowiązywał do zakładania szkół, nauczania i wychowywania dzieci i młodzieży. Omawiał zagadnienia postu i jego znaczenia w życiu chrześcijanina podając wykaz postów. Poświęcił także synod wiele miejsca kwestii świąt i świętowania, sodalicji i bractw kościelnych. Ostatnim omawianym zagadnieniem były kary kościelne ${ }^{27}$.

W dość przystępnych i obszernych uchwałach synodalnych biskup Karnkowski przedstawił duchowieństwu i wiernym dokumenty soborowe. Były w nich zawarte zarządzenia ściśle prawne, dyscyplinarne i administracyjne, ale także wyjaśnienia dogmatyczne, przez które Karnkowski pragnął dotrzeć z nieskażona nauką Kościoła do duchowieństwa i różnych grup wiernych. Zobowiązał wszystkich do ich zachowywania, a jednocześnie do wzajemnej braterskiej kontroli. Na synodzie główną uwagę zwrócono przede wszystkim na sprawy i problemy duszpasterskie w diecezji, jego ożywienie i odnowę życia religijno-moralnego. Zawartemu $\mathrm{w}$ artykułach materiałowi należy przyznać znaczny stopień systematyczności, a także przejrzystości, co powodowało, że uchwały synodalne były zrozumiałe dla duchowieństwa i wiernych.

Synod ten był jednym $\mathrm{z}$ najważniejszych wydarzeń $\mathrm{w}$ procesie recepcji Tridentinum, a o jego wadze świadczy fakt, że był on punktem odniesienia dla wielu późniejszych synodów diecezji

\footnotetext{
${ }^{26}$ Acta synodi dioecesanae Wladislaviae Anno 1568 per Stanislaum Karnkowski episcopum celebratae, Z. CHODYŃsKi, Statuta synodalia..., 56-62.

${ }^{27}$ Tamże, s. 62-70.
} 
kujawsko-pomorskiej. Uchwały synodu biskup Karnkowski, aczkolwiek nie musiał tego czynić, gdyż nie wymagały tego przepisy prawa powszechnego, wysłał do Rzymu, by tam zostały zaaprobowane. Papież Pius V listem z dnia 22 maja 1568 r. chwalił gorliwość biskupa kujawsko-pomorskiego pisząc: zwołałeś bowiem synod diecezjalny, na którym dołożyłeś starania, ażeby całe duchowieństwo uczyniło wyznanie wiary katolickiej, powołałeś także na podstawie dekretu soborowego seminarium i życzył mu silnej woli i konsekwencji we wprowadzaniu odnowy Kościoła włocławskiego ${ }^{28}$.

Należy podkreślić, że jest to pierwszy synod w historii diecezji włocławskiej, którego uchwały i dokumenty zostały wydane i ogłoszone drukiem w Kolonii u M. Cholina w roku 1572 pod tytułem Constitutiones in dioecesana synodo Wladislaviensis presidente [...] de Stanislao Carcovio episcopo Vladislaviensi ${ }^{29}$. Tym samym uchwały synodu, jakże ważnego i przełomowego, wytyczającego drogę reformie trydenckiej w diecezji, odnowie duszpasterstwa i życia religijno-moralnego, stawały się jeszcze bardziej punktem odniesienia zarówno dla duszpasterzy, jak i administracji oraz sądownictwa kościelnego.

\subsection{Synod z 1579 roku}

Drugi swój synod biskup Karnkowski zwołał pismem konwokacyjnym z dnia 20 lutego 1579 r. wydanym w Raciążku. Zwołał on wszystkich zobowiązanych do udziału w obradach synodalnych na dzień 28 kwietnia tegoż roku do Włocławka. Karnkowski zwołał ten synod, aby zadośćuczynić wymaganiom dekretu Soboru Trydenckiego o synodach diecezjalnych i aby zapoznać się w wypełnianiem przez duchowieństwo zarządzeń Soboru i synodu diecezjalnego z 1568 r. O zamiarze zwołania i odbycia synodu biskup Karnkowski powiadomił nuncjusza

\footnotetext{
${ }^{28}$ Acta synodi dioecesanae Wladislaviae Anno 1568 per Stanislaum Karnkowski episcopum celebratae, Z. CHODYŃsKi, Statuta synodalia..., s. 79.

${ }^{29}$ Wydania tego nie ma w Bibliotece Wyższego Seminarium Duchownego we Włocławku. Znał je i na jego podstawie opublikował statuty synodalne tego synodu Z. CHODYŃski w swoim zbiorze Statuta synodalia dioecesis Wladislaviensis et Pomeraniae, Varsaviae 1890 . Nie ma też akt rękopiśmiennych tego synodu w Archiwum Diecezji Włocławskiej.
} 
apostolskiego w Polsce Giovanniego Andrea Caligariego, prosząc go o przewodniczenie temuż zgromadzeniu ${ }^{30}$. Nuncjusz jednak ze względu na inne zajęcia nie mógł przybyć na synod.

Dokument synodalny nie jest już tak obszerny i dogłębnie opracowany jak poprzedni. Przypominał on w krótkim kompedium główne myśli i dekrety Tridentinum, do których pełnego zachowania biskup raz jeszcze gorąco i usilnie wzywał i zobowiązywał odsyłając do poprzedniego swego synodu, który gruntownie wyłożył i przybliżył doktrynę i prawo soborowe. W swej zasadniczej części synod poświęcony był reformie podupadłej kapituły kruszwickiej św. Piotra i Pawła ${ }^{31}$. Uchwały synodalne podejmowały następujące tematy: składanie wyznania wiary przez duchownych, uzyskanie aprobaty od biskupa do głoszenia kazań, obowiązek rezydencji oraz posiadania dokumentów Soboru Trydenckiego, Katechizmu Rzymskiego, Brewiarza Rzymskiego i ksiąg do udzielania sakramentów, szczególnie chrztu i małżeństwa oraz Eucharystii i pokuty, zakazu sprzedawania dóbr kościelnych i otrzymywania beneficjum tylko przez posiadających święcenia kapłańskie, noszenie stroju duchownego i prowadzenie życia godnego i moralnego przez duchownych, właściwe funkcjonowanie zakonów w diecezji, sprawy seminarium duchownego powołanego przez biskupa na poprzednim synodzie ${ }^{32}$.

Uchwały synodu, podobnie jak poprzedniego, wiele miejsca poświęcały formacji duchowej i intelektualnej przygotowujących się do święceń, obowiązkom duchowieństwa, szczególnie proboszczów i tych wszystkich którzy zajmowali się duszpasterstwem. Nadto zwracały uwagę i porządkowały struktury życia religijnego i kościelnego diecezji. Były one rozwinięciem oraz pewnego rodzaju dopełnieniem uchwał synodalnych z $1568 \mathrm{r}^{33}$

\footnotetext{
${ }^{30}$ Z. Chody Ński, Statuta synodalia..., s. XXX.

${ }^{31}$ Secunda synodus dioecesana Stanislai Karnkowski, Wladislaviae Anno Domini 1579 celebrata, Z. CHODyŃski, Statuta synodalia..., s. 80.

${ }^{32}$ Tamże, s. 80-86.

${ }^{33}$ Por. J. GRęźLIKowski, Recepcja reformy trydenckiej..., s. 145-146.
} 
Urzędowa kopia uchwał synodalnych została wpisana do Akt Biskupów Kujawskich i Pomorskich. Z niej korzystał ks. Z. Chodyński kiedy redagował treść wszystkich znanych synodów włocławskich opublikowanych we wspomnianych Statuta synodalia dioecesis Wladislaviensis et Pomeraniae. Uchwały synodalne zostały poprzedzone spisem zacniejszych uczestników synodu oraz przedstawieniem dekretu zwołującego synod. Obecnie w Archiwum Diecezji Włocławskiej akt tych nie ma. Wzmiankę zaś o synodzie można znaleźć w Acta Capituli Wladislaviensi ${ }^{34}$.

\section{Reaktywowanie i reorganizacja struktur administracyjnych diecezji}

Kiedy biskup Karnkowski objął diecezję włocławską, czyli kujawsko-pomorską rozciągała się ona długim pasem wzdłuż lewego (zachodniego) brzegu Wisły, w nielicznych miejscach przechodząc na jej brzeg wschodni; zaczynając się na południu od Lubienia, Przedcza i Brdowa, rozciągała się w stronę północy poprzez Włocławek, Kruszwicę, Inowrocław, Bydgoszcz, Pelplin, aż do samych brzegów Bałtyku, do Gdańska, Pucka i Łeby. Obejmowała więc całe Kujawy, wschodnie Pomorze, zwane Pomorzem Gdańskim z ziemią lęborską i bytowską. ${ }^{35}$ Była podzielona na trzy archidiakonaty: włocławski, kruszwicki i pomorski. ${ }^{36}$ Posiadała oficjalaty: generalny włocławski, zwany też kujawskim, okręgowy gdański, który stopniowo przekształcił się w generalny, nazywany też pomorskim i okręgowy bydgoski. ${ }^{37}$ Podzielona była na 14 dekanatów: 7 w części kujawskiej diecezji: włocławski, brzeski, inowrocławski, radziejowski, raciążski, bydgoski i kruszwicki oraz 7 w części pomorskiej: świecki, nowski,

\footnotetext{
${ }^{34}$ Archiwum Diecezji Włocławskiej, Akta Kapituły Katedralnej, Nr 5(219) k. 7.

${ }^{35}$ B. Kumor, Granice metropolii i diecezji polskich (968-1939), Archiwa Biblioteki i Muzea Kościelne 19(1969) s. 298-299; I. Suber A, Terytorium diecezji włocławskiej i pomorskiej, Warszawa 1962, s. 28-31.

${ }^{36}$ S. Librowski, Wizytacje diecezji włocławskiej..., s. 65-66.

${ }^{37}$ P. HempereK, Oficjalaty okręgowe w Polsce, Roczniki Teologiczno-Kanoniczne 18(1971) z.5, s. 52-55.
} 
lęborski, tczewski, pucki, kościerzyński i starogardzki. ${ }^{38}$ Ważną strukturą $\mathrm{w}$ organizacji duszpasterskiej diecezji były też parafie - podstawowe formy zorganizowanego życia religijnego. $\mathrm{W}$ drugiej połowie XVI wieku (1577 r.) na Kujawach było 118 kościołów parafialnych. ${ }^{39}$ W części pomorskiej diecezji znajdowało się około 148 kościołów parafialnych. Z ogólnej sumy 266 parafii w $1583 \mathrm{r}$. lub według innych danych z 272 kościołów, 190 kościołów znajdowało się we władaniu innowierców. ${ }^{40}$ Zdarzało się, że jeden kapłan musiał obsługiwać dwa lub trzy kościoły. ${ }^{41}$ Sytuacja zatem nie była optymistyczna, a rozwój protestantyzmu w diecezji nie przebiegał spokojnie, bowiem innowiercy, szczególnie w części pomorskiej diecezji przejmowali kościoły i dominowali swoimi reformatorskimi poglądami i zachowaniami ${ }^{42}$.

Biskup Stanisław Karnkowski w listach do kardynała Hozjusza wyrażał ubolewanie nad stanem diecezji. Za głównego sprawcę tego stanu uważał Andrzeja Prażmowskiego, który, jak pisał „wynosił i znosił ministrów, założył szkołę dla dzieci szlacheckich, agitował na reformację mieszkańców miast królewskich w Brześciu, Nieszawie, Radziejowie, Bydgoszczy i Inowrocławiu. Pod jego wpływem szlachta zamykała w swych posiadłościach kościoły, znosiła klasztory, wypędzała księży" "3. Pocieszał tylko biskupa fakt, że wśród innowierców kujawskich panowała niezgoda. Nadto poważnym utrudnieniem pracy duszpasterskiej był brak odpowiedniego wykształcenia wśród duchowieństwa oraz niski jego poziom moralny, a także słabe przygotowanie do pracy duszpasterskiej w obliczu oddziaływania innowierców.

\footnotetext{
${ }^{38}$ Z. CHODYŃsKI, Statuta synodalia..., s. IX.

${ }^{39} \mathrm{~J}$. KŁoczowskI, Uwagi wstępne . Chrześcijaństwo polskie XVI-XVIII wieku, w: Kościół w Polsce, pr. zb. pod red. J. Kłoczowskiego, t. II, Kraków 1970, s. 281-282; Zob. S. Chodý́ski, Włocławska diecezja, w: Encyklopedia Nowodworskiego, t. XXXII, Płock 1913, s. 60.

${ }^{40}$ Zob. S. Chody ́́ski, Monumenta historica wladislaviensis, t. I, Wladislaviae 1881, s. 24.

${ }^{41}$ Tamże, t. VII, Wladislaviae 1887, s. 77-78.

${ }^{42}$ J. KŁoczowski, Uwagi wstępne..., s. 39-53.

${ }^{43}$ L. Dомвек, Reformacja na Kujawach w XVI wieku, Prace Wydziału Nauk Humanistycznych Bydgoskiego Towarzystwa Naukowego, seria C, 4(1966) s. 60-61.
} 
Taki stan rzeczy w obliczu rozwijającej się reformacji wymagał głębokiej naprawy i natychmiastowej promulgacji nowych wymogów działalności duszpasterskiej jakie przyniosły uchwały Soboru Trydenckiego i podporządkowania się im oraz zdecydowanego podjęcia ich w zarządzeniach synodalnych. Stąd - jak zobaczymy - synody biskupa Karnkowskiego realizowały trud poważnej i gruntownej reformy duszpasterstwa, a tym samym podejmowały niejako ofensywną akcję duszpasterską, która nie była jednak łatwą i prostą do przeprowadzenia.

Powyższa sytuacja powodowała również, iż Karnkowski opierając się na zastanej sieci dekanalnej podjął próbę uaktywnienia działalności dziekanów, czemu dał wyraz na pierwszym swoim synodzie odbytym $1568 \mathrm{rr}^{44}$ Powodowane to było tym, iż istniejące dekanaty na czele z dziekanami nie zawsze spełniały swoje zadania, a poprzednicy biskupa Karnkowskiego na stolicy biskupiej niejednokrotnie zaniedbywali mianowanie dziekanów lub też istnieli oni tylko nominalnie. Biskup Karnkowski przypominając polecenie synodu prowincjonalnego warszawskiego z 1561 r., który nakazywał przywrócenie urzędu dziekana w celu czuwania nad karnością, dyscypliną i życiem podległego sobie duchowieństwa ${ }^{45}$ reaktywował ich działalność, mianował brakujących dziekanów i zobowiązał ich do zbierania dwa razy w roku kapłanów na kongregacje dekanalne, „by tępić wszelkie nadużycia stanu kapłańskiego i wspólnie radzić nad sprawami duszpasterstwa”. Podkreślając rolę i znaczenie urzędu dziekańskiego, biskup Karnkowski zobowiązywał dziekanów, aby wyznaczali miejsce zebrań dekanalnych dwa razy w roku i gromadząc duchowieństwo "przeegzaminowali ich z nauki i życia” oraz przekazywali potrzebne wiadomości z teologii i prawa ${ }^{46}$. Stworzyło to lepsze i dogodniejsze

\footnotetext{
${ }^{44}$ Acta synodi dioecesanae Wladislaviae Anno 1568 per Stanislaum Karnkowski episcopum celebratae, Z. Chody Ńsкi, Statuta synodalia..., s. 45.

${ }^{45}$ I. SUBERA, Synody prowincjonalne arcybiskupów gnieźnieńskich, Warszawa 1981, s. 106.

${ }^{46}$ Acta synodi dioecesanae Wladislaviae Anno 1568 per Stanislaum Karnkowski episcopum celebratae, Z. CHOdÝ́ski, Statuta synodalia..., s. 66.
} 
warunki dla duszpasterskiej kontroli proboszczów przez dziekanów oraz wychodziło naprzeciw odnowie duszpasterstwa, na co zwracał szczególną uwagę Sobór Trydencki.

\section{Powołanie do życia seminarium duchownego}

Bezpośredni związek z odnową duszpasterstwa miało powołanie do życia przez biskupa Karnkowskiego seminarium duchownego we Włocławku, a także podjęcie działań zmierzających do utworzenia seminarium duchownego dla pomorskiej części diecezji w Gdańsku. Zdawał sobie bowiem sprawę, że konieczna jest instytucja kształtująca i przygotowująca przyszłych kapłanów przede wszystkim do pracy w duszpasterstwie. Stąd mając na uwadze dekret Tridentinum Cum adolescentium aetas $\mathrm{z}$ dnia 8 maja 1563 r., który zobowiązywał każdą diecezję do posiadania własnego seminarium duchownego, ${ }^{47}$ nadto dostrzegając pilną potrzebę kształcenia kandydatów do kapłaństwa i ich praktycznego przygotowania do duszpasterstwa, przedstawił zgromadzonym na synodzie w 1568 r. naglącą konieczność założenia seminarium duchownego. ${ }^{48}$ Określił na ten cel środki materialne na sumę 1000 złotych polskich w stosunku rocznym. Od biskupa Karnkowskiego miała pochodzić kwota 600 złotych, z trzech opactw cysterskich diecezji: Koronowa, Pelplina i Oliwy - po 100 złotych oraz wspólnie 100 złotych mieli złożyć trzej prepozyci zakonni - kartuski, benedyktynek żarnowieckich i dominikanek żukowskich. ${ }^{49}$ Za zgodą swej kapituły katedralnej i zebranego na synodzie duchowieństwa, ufundował je 16 marca 1568 r., jako pierwsze na ziemiach tzw. rdzennej Polski, a trzecie w obecnych granicach Polski. ${ }^{50}$

\footnotetext{
${ }^{47}$ Conc. Trid., sess. XXIII, c. 18 de ref.

${ }^{48}$ Z. Chodý́ski, Statuta synodalia..., s. XIII, 47; Zob. S. Librowski, Czterechsetlecie fundacji Seminarium Włocławskiego (1568-1968), Archiwa, Biblioteki i Muzea Kościelne 17(1968), s. 179.

${ }^{49}$ Acta synodi dioecesanae Wladislaviae Anno 1568 per Stanislaum Karnkowski episcopum celebratae, Z. CHodý́ski, Statuta synodalia..., s. 47.

${ }^{50}$ A. Petrani, Nauka prawa kanonicznego $w$ Polsce $w$ XVIII $i$ XIX wieku, Lublin 1961, s. 14-15; zob. S. Librowski, Właściwie, które seminarium w Polsce jest najstarsze?, Archiwa, Biblioteki i Muzea Kościelne 17(1968), s. 185-189.
} 
Fundacja seminarium włocławskiego została zatwierdzona wraz ze statutami synodu 22 maja 1568 r. przez Piusa V. ${ }^{51}$ Posiadając potwierdzenie fundacji seminarium, po rocznych przygotowaniach i realizacji zaplanowanych na synodzie oraz przewidzianych później środków materialnych, dnia 16 sierpnia 1569 r., na zebraniu generalnym kapituły katedralnej i za jej zgodą, biskup Karnkowski wydał dokument erekcji Seminarium Duchownego we Włocławku. ${ }^{52} \mathrm{~W}$ dyspozycji dokumentu erekcyjnego położył ogólne zręby organizacyjne nowej instytucji. Wytyczył kwestie utrzymania seminarium, określił kierownictwo naukowe i wychowawcze, podał precyzyjnie program nauczania. $^{53}$

Seminarium włocławskie zaczęło funkcjonować zaraz po swej fundacji, a przynajmniej po erekcji. Brak należytego pomieszczenia, zarazy nawiedzające miasto biskupie oraz brak trwałego funduszu na utrzymanie seminarium nie sprzyjały jego rozwojowi. Opaci w Koronowie, Oliwie i Pelplinie oraz przełożeni klasztorów w Kartuzach, Żarnowcu i Żukowie nie wywiązywali się ze swych zobowiązań podpisanych na synodzie w 1568 r. ${ }^{54} \mathrm{Na}$ skutek powyższych trudności i okoliczności nie zdołał biskup rozwinąć, a nawet utrzymać swego dzieła. Przechodząc w roku 1581 na stolicę gnieźnieńską, musiał pozostawić seminarium bez profesorów i alumnów. ${ }^{55}$

Dostrzegając szerzący się protestantyzm w części pomorskiej diecezji, w wyniku którego zagrożony został nie tylko katolicyzm, ale i polskość tych ziem, pragnął zabezpieczyć miejscowej ludności opiekę duszpasterską przez dostarczenie odpowiednio przygotowanego

\footnotetext{
${ }^{51}$ Acta synodi dioecesanae Wladislaviae Anno 1568 per Stanislaum Karnkowski episcopum celebratae, Z. ChodyŃsкi, Statuta synodalia..., s. 47; zob. S. Librowsкi, Czterechsetlecie fundacji..., s. 181.

${ }^{52}$ S. Librowski, Czterechsetlecie erekcji Seminarium Włocławskiego (1569-1969), Archiwa Biblioteki i Muzea Kościelne 18(1969), s. 125.

${ }^{53}$ Tamże, s. 127; zob. S. Szczeblewski, Seminaria duchowne diecezji włocławskiej, Ateneum Kapłańskie 72(1969), s. 238-239.

${ }^{54}$ Secunda synodus dioecesana Stanislai Karnkowski, Wladislaviae Anno Domini 1579 celebrata, Z. CHоDyŃski, Statuta synodalia..., s. 82.

${ }^{55}$ S. Librowski, Czterechsetlecie fundacji..., s. 183.
} 
duchowieństwa. Dlatego myślał o stworzeniu fundacji na założenie jeśli nie seminarium, to przynajmniej kolegium jezuickiego w Gdańsku $^{56}$. Przeniesiony z Włocławka do Gniezna, nie zdołał zrealizować swoich planów. Zdołał tylko przeznaczyć trzecią część alumnów w ufundowanym seminarium włocławskim (8 na 24 alumnów) na potrzeby części pomorskiej diecezji.

\section{Obowiązki i zadania duszpasterskie proboszczów}

Synody biskupa Karnkowskiego, szczególnie pierwszy z 1568 r., dużą wagę przywiązywały do obowiązków duszpasterskich beneficjatów - duszpasterzy, głównie proboszczów. W oparciu o zarządzenie Soboru Trydenckiego i konstytucji Piusa IV, wszyscy beneficjaci obejmujący beneficja duszpasterskie zobowiązani byli przy instalacji do złożenia wyznania wiary ${ }^{57}$. Złożenie publicznego wyznania wiary miało według obydwu synodów urzeczywistniać nieskazitelność wiary u osób duchownych oraz stanowić fundamentalny element budowania wspólnoty Kościoła opartej o soborowy wykład wiary i dyscypliny kościelnej.

Następnym elementem owocnego prowadzenia duszpasterstwa były polecenia synodalne wzywające proboszczów i duszpasterzy do rezydencji. To duchowni - zdaniem biskupa Karnkowskiego - „więcej niż inni muszą czuwać, pracować i trudzić się w Winnicy Pańskiej, gdyż są pasterzami”. Z tego powodu zobowiązani byli na stale przebywać w swoich parafiach i opuszczać je jak najrzadziej. Winni „znać swoich parafian, ofiarować za nich Mszę św., głosić im słowo Boże, szafować sakramenty, budować ich przykładem własnego życia i dobrych dzieł, otaczać ojcowską opieką biednych i potrzebujących oraz rozwijać różne formy kultu Bożego. Wypełnienie tych wszystkich zadań nie byłoby możliwe bez rezydencji duszpasterza, który „nie

\footnotetext{
${ }^{56}$ S. Szczeblewski, Seminaria duchowne..., s. 255-256.

${ }^{57}$ Acta synodi dioecesanae Wladislaviae Anno 1568 per Stanislaum Karnkowski episcopum celebratae, Z. CHODYŃski, Statuta synodalia..., s. 56-57; Secunda synodus dioecesana Stanislai Karnkowski, Wladislaviae Anno Domini 1579 celebrata, Z. Chodyński, Statuta synodalia..., s. 82.
} 
może być najemnikiem opuszczającym swoją trzodę" ${ }^{58}$. Polecenie to raz jeszcze i to dwukrotnie, tylko w formie krótszej, powtarzał prawodawca synodalny na synodzie w $1579 \mathrm{r}^{59}$

Synod z 1568 r. polecał proboszczom - co też należało do obowiązków duszpasterskich - poznanie heretyków i publicznych grzeszników, zwłaszcza gorszycieli naruszających dni świąteczne, bluźnierców, konkubinariuszy, cudzołożników i lichwiarzy. Byli oni zobowiązani odwodzić ich od zła, a w wypadkach potrzeby, nazwiska tego rodzaju parafian mieli donieść biskupowi ${ }^{60}$.

Do zadań i obowiązków duszpasterskich synod z 1568 r. zaliczał także troskę proboszczów o ludzi biednych, wdowy, sieroty i chorych. W pierwszym rzędzie powinni oni doznawać pomocy duchowej swoich duszpasterzy, a także i materialnej. Gdy zaś sami duszpasterze nie byli w stanie świadczyć takiej pomocy materialnej, winni zachęcić do spełnienia tej powinności chrześcijańskiej osoby zamożniejsze. Specjalną opieką duszpasterską proboszczowie powinni otoczyć pracowników kościelnych, nauczających w szkołach oraz ich rodziny ${ }^{61}$. Szczególnym zadaniem duszpasterskim proboszczów, według biskupa Karnkowskiego, było otoczenie opieką duszpasterską nauczycieli pracujących w szkołach parafialnych, gdyż to oni przekazywali prawdy wiary i uczyli dzieci i młodzież dobrych obyczajów. Karnkowski stwierdzał w statucie synodalnym z 1568 r. że „szkoła jest tym miejscem, gdzie rozstrzyga się przyszłość Kościoła i Rzeczypospolitej. Dlatego w dobie zagrożenia reformacją uczniowie potrzebują nie tyle nauczycieli, co świadków, a szkoła winna być integralną częścią Kościoła" ${ }^{62}$. Stąd opieka duszpasterska nad uczącymi w szkole

\footnotetext{
${ }^{58}$ Acta synodi dioecesanae Wladislaviae Anno 1568 per Stanislaum Karnkowski episcopum celebratae, Z. CHodyńsкi, Statuta synodalia..., s. 51-52.

${ }^{59}$ Secunda synodus dioecesana Stanislai Karnkowski, Wladislaviae Anno Domini 1579 celebrata, Z. CHODYŃski, Statuta synodalia..., s. 82-83.

${ }^{60}$ Acta synodi dioecesanae Wladislaviae Anno 1568 per Stanislaum Karnkowski episcopum celebratae, Z. CHodyński, Statuta synodalia..., s. 52.

${ }^{61}$ Tamże, s. 52-53.

${ }^{62}$ Tamże, s. 72 .
} 
parafialnej była elementem ważnym. Nadto synod stawiał konkretne wymagania wszystkim uczącym w szkole parafialnej ${ }^{63}$.

\section{Przekaz wiary i nauczanie}

Bardzo znaczącą dziedziną odnowy duszpasterstwa był przekaz wiary, głównie jej obrona i troska o jej nieskazitelność oraz nauczanie. To od nich - zdaniem biskupa Karnkowskiego - zależał wzrost poziomu życia religijno-moralnego wiernych diecezji kujawsko-pomorskiej. Stąd - jak wspomniano - już na synodzie w $1568 \mathrm{r}$. w rozdziale De fidei professione et eius forma nakazywał wszystkim kapłanom - duszpasterzom złożenie wyznania wiary określając jego formę i sposób $b^{64}$. To samo z jeszcze większym naciskiem czynił na synodzie w 1579 r. ${ }^{65}$ Professio fidei stanowiło konieczny warunek wszelkiej pracy duszpasterskiej, która winna prowadzić do świętości i strzeżenia depozytu wiary, bowiem - jak twierdził biskup Karnkowski - „wiara jest fundamentem religii, bez której ani Kośció nie ma racji swego istnienia, ani ludzie nie mogą podobać się Bogu, a w naszych czasach trzeba ukazać ludziom w czyich rękach znajduje się prawdziwy skarbiec wiary chrześcijańskiej" ${ }^{\prime 66}$. Celem zachowania czystości depozytu wiary w działaniach duszpasterskich, statut synodalny z 1568 r. nie pozwalał proboszczom dopuszczać do głoszenia kazań tych duchownych, którzy byli podejrzani o herezję czy jej sprzyjanie $^{67}$. Jednocześnie zabraniał pod karą interdyktu wszystkim

\footnotetext{
${ }^{63} \mathrm{Na}$ stanowisko nauczyciela nie wolno było proboszczowi zatrudnić osoby podejrzanej o herezję i prowadzącej niemoralny tryb i styl życia. Każdy kierownik szkoły parafialnej winien być zatwierdzony przez biskupa lub jego oficjała. Nauczyciele musieli składać wyznanie wiary, co stanowiło warunek konieczny do zatrudnienia, a także zobowiązani byli do dobrego przykładu życia w dziedzinie moralności i metod nauczania. Tamże, s. 72-73.

${ }^{64}$ Tamże, s. 56-57.

${ }^{65}$ Secunda synodus dioecesana Stanislai Karnkowski, Wladislaviae Anno Domini 1579 celebrata, Z. СноруŃsкi, Statuta synodalia..., s. 82.

${ }^{66}$ Acta synodi dioecesanae Wladislaviae Anno 1568 per Stanislaum Karnkowski episcopum celebratae, Z. CHodý́sкi, Statuta synodalia..., s. 39 i 80-81.

${ }^{67}$ Tamże, s. 71.
} 
głoszącym słowo Boże korzystania z opracowań heretyckich lub sugerowania się ich wypowiedziami i naukami, bowiem „komentarze heretyckie mogą się jedynie przyczynić do upadku słuchających ${ }^{68}$.

Poważnym zagrożeniem dla czystości wiary i efektywności działań duszpasterskich była działalność wędrownych kapłanów, kaznodziejów i egzorcystów, głoszących słowo Boże bez zgody miejscowego biskupa. Stąd na synodzie z 1579 r. zagroził proboszczom, pod karą suspensy, dopuszczania do praktyk duszpasterskich obcych kapłanów, którzy nie mieli na to pisemnej zgody biskupa lub jego wikariusza ${ }^{69}$.

Mając na uwadze wzrost poziomu życia religijno-moralnego wiernych biskup Karnkowski w swoich statutach synodalnych zwracał również uwagę na dziedzinę nauczania religijnego. W pierwszym rzędzie zwracał uwagę na sprawę głoszenia słowa Bożego przez duszpasterzy. W rozdziale De parochorum officio, et aliorum curam animarum habentium wzywał na samym wstępie duszpasterzy do głoszenia zdrowej nauki, wolnej od wszelkiego błędu i herezji, mającej na celu nauczanie prawd wiary i moralności; podkreślał, iż $\mathrm{w}$ parze $\mathrm{z}$ przepowiadaniem powinien iść odpowiedni poziom życia duchowego nauczających. Treść nauczania kaznodziejskiego winna stanowić całość nauki objawionej zawarta przede wszystkim w Składzie Apostolskim, Modlitwie Pańskiej, Dekalogu i sakramentach św., nadto treścią przepowiadania powinny być - według ustawodawcy synodalnego - zagadnienia $z$ sakramentologii, a także zobowiązania wypływające z faktu przyjęcia chrztu. Biskup Karnkowski przypominał wielką odpowiedzialność przed Bogiem za wszelkie zaniedbania duchowieństwa w tym względzie, one bowiem gorliwie wykonane „będą prawdziwym światłem dla błądzących oraz pobudzą i ożywią skuteczność i owocność pracy duszpasterskiej”. Polecał kaznodziejom, aby posługiwali się komentarzami do Pisma Świętego, ale tylko uznanych przez Kościół doktorów, zarówno dawnych, jak i nowszych. Kategorycznie zabraniał korzystania z komentarzy wydanych przez

\footnotetext{
68 Tamże, s. 72.

${ }^{69}$ Secunda synodus dioecesana Stanislai Karnkowski, Wladislaviae Anno Domini 1579 celebrata, Z. Chodý́ski, Statuta synodalia..., s. 84.
} 
innowierców oraz zabronionych przez indeks rzymski. Nakazywał, aby głoszący słowo Boże zaopatrzyli się w odpowiednie pomoce, tj. książki zawierające wykład wiary katolickiej. Wskazywał na pomocną i konieczną rolę Katechizmu Rzymskiego i postyllę - wykład Ewangelii Jakuba Wujka, opracowany w języku polskim, które miały być do diecezji sprowadzone ${ }^{70}$.

Pierwszy synod potrydencki diecezji włocławskiej nakazywał duszpasterzom, aby po skończonym niedzielnym kazaniu głośno razem z wiernymi odmawiali Modlitwę Pańską, Pozdrowienie Anielskie oraz Skład Apostolski, aby w ten sposób wierni mieli okazję i sposobność nauczyć się i zapamiętać te modlitwy. W okresie Wielkiego Postu i Adwentu duszpasterze do powyższych modlitw odmawianych z wiernymi mieli dodawać jeszcze Dziesięć przykazań Bożych oraz spowiedź powszechną ${ }^{71}$. Ponadto, zgodnie z postulatem Tridentinum, biskup nakładał na głoszących słowo Boże obowiązek pouczania wiernych czym jest Msza święta, jakie zawiera w sobie tajemnice i duchowe owoce oraz wyjaśniania poszczególnych prawd wiary zawartych w Katechizmie Rzymskim, a przede wszystkim dotyczących sakramentów. Nadto kaznodzieje zostali zobowiązani do przypominania wiernym wykazu dni świątecznych z jednoczesną zachętą zmierzającą do godnego ich przeżywania ${ }^{72}$.Z powyższych zarządzeń synodalnych wynikała troska ustawodawcy o podniesienie wiedzy religijnej wśród wiernych, co miało służyć także odnowie duszpasterstwa. Religijność bowiem wieku XVI bogata była w obrzędy, ale uboga doktrynalnie. Głoszenie kazań miało stanowić zaporę dla sensualizmu religijnego i przyczyniać się do odnowy duszpasterstwa ${ }^{73}$.

W dalszym ciągu statut synodalny biskupa Karnkowskiego z $1568 \mathrm{r}$. przypominał, iż nikomu - poza proboszczami oraz kaznodzieją

\footnotetext{
${ }^{70}$ Acta synodi dioecesanae Wladislaviae Anno 1568 per Stanislaum Karnkowski episcopum celebratae, Z. Chodyńsкi, Statuta synodalia..., s. 57.

${ }^{71}$ Tamże, s. 57.

${ }^{72}$ Tamże.

${ }^{73} \mathrm{~J}$. KRACIK, Katolicka indoktrynacja doby saskiej w parafiach zachodniej Małopolski, Roczniki Teologiczno-Kanoniczne 20(1973) z. 6, s. 14.
} 
katedralnym i kolegiackimi - nie wolno wygłaszać kazań bez uprzedniej aprobaty biskupiej. Kaznodzieje zakonni mogli głosić słowo Boże w kościołach swojego zakonu, po uprzednim jednak okazaniu biskupowi zezwolenia własnych przełożonych. Powyższy zakaz został obwarowany sankcją karną nieokreśloną ${ }^{74}$. Powyższe zarządzenia zostały skrótowo ponownie przypomniane na synodzie w 1579 r. $^{75}$

Oprócz nauczania zasad wiary i postępowania poprzez głoszenia słowa Bożego, biskup Karnkowski mając na celu odnowę życia religijno-moralnego i duszpasterstwa, zwracał uwagę na rolę nauczania katechetycznego, które miało stanowić drugą formę nauczania prawd wiary i moralności. Statuty synodalne oby synodów zobowiązywały proboszczów do nauczania, zarówno dorosłych jak i dzieci, pacierza i podstawowych prawd wiary. A zatem przedmiotem tego nauczania miała być: Modlitwa Pańska, Zdrowaś Mario i Skład Apostolski, Deka$\log$, znaczenie i wartość Mszy świętej, przystępowania do spowiedzi i Komunii świętej oraz podstawy pobożności chrześcijańskiej ${ }^{76}$. Fundamentem i podstawą tego nauczania miał być Katechizm trydencki. Biskup Karnkowski nakazywał proboszczom nauczać wiernych pacierza i znaku Krzyża po kazaniu w czasie sprawowanej Mszy świętej, natomiast prawd wiary i moralności w czasie każdej sposobności. Polecał także, aby proboszczowie odwiedzali domy powierzonych swojej opiece duszpasterskiej parafian i pilnie interesowali się tym, jaka jest ich wiedza religijna. Nadto mieli obowiązek napominania rodziców, aby lepiej czuwali nad religijną edukacją dzieci ${ }^{77}$. Zarządzenie biskupa Karnkowskiego miało na celu rozszerzenie nauczania

\footnotetext{
${ }^{74}$ Acta synodi dioecesana Wladislavienae anno 1568 per Stanislaum Karnkowski episcopum celebratae, Z. CHody Ński, Statuta synodalia...., s. 57.

${ }^{75}$ Secunda synodus dioecesana Stanislai Karnkowski, Wladislaviae Anno Domini 1579 celebrata, Z. CHODYŃsKi, Statuta synodalia...., s. $82-83$.

${ }^{76}$ Acta synodi dioecesanae Wladislaviae anno 1568 per Stanislaum Karnkowski episcopum celebratae, Z. Chodý́sкi, Statuta synodalia...., s. 56-57; Secunda Synodus Dioecesana Stanislai Karnkowski, Wladislaviae Anno Domini 1579 celebrata, Tamże, s. 82-83.

${ }^{77}$ Secunda synodus dioecesana Stanislai Karnkowski, Wladislaviae Anno Domini 1579 celebrata, Tamże, s. 83.
} 
religijnego w zakresie prawd katechizmowych, które było bardzo zaniedbane, co też miało służyć odnowie duszpasterstwa.

Nauczanie religijne w szkołach parafialnych to kolejna forma przekazywania prawd wiary i zasad moralności chrześcijańskiej, co także miało swoje znaczenie dla odnowy duszpasterstwa, a o co tak dobitnie apelował Sobór Trydencki ${ }^{78}$. Nauczanie szerszego ogółu wiernych w tym okresie wynikało przede wszystkim z pojawienia się i gwałtownego rozszerzania reformacji. Pragnąc ożywić wiarę i życie religijno-moralne oraz przywiązanie do Kościoła katolickiego, biskup Karnkowski upatrywał w nich przeciwdziałanie reformacji oraz wzmocnienie katolicyzmu szerokich mas społeczeństwa, a także wzrost uświadomienia religijnego i poziomu kultury chrześcijańskiej, co miało również służyć odnowie duszpasterstwa ${ }^{79}$. Zdawał sobie sprawę, że narastającym zagrożeniom dla wiary katolickiej ze strony innowierców mogą stawić czoło tylko ludzie wykształceni. Stąd też pragnął, aby szkoły parafialne służyły przede wszystkim praktycznym potrzebom Kościoła, a także wychowaniu chrześcijańskiemu dzieci i młodzieży. Stąd na synodzie z 1568 r., w rozdziale De Scholis, pod groźbą kar kościelnych bliżej nie sprecyzowanych, nakazywał by rządcy kościołów prowadzili szkoły parafialne, troszczyli się o nie i za-

\footnotetext{
${ }^{78}$ Obowiązek zakładania i utrzymania szkół na terenie parafii w całym Kościele Zachodnim nakazał Sobór Laterański IV (1215 r.). Sprawa ta nabrała szczególnej aktualności na forum Soboru Trydenckiego, gdzie zapotrzebowanie na szkoły parafialne znalazło swe odbicie w uchwałach soborowych. Od połowy XVI wieku do pierwotnych celów szkolnej edukacji na stopniu elementarnym dołączono jeszcze jeden motyw: wykształcenie i wychowanie religijno-moralne. Należy pamiętać, że w Polsce szkoła, oprócz szpitala, aż do czasów Komisji Edukacji Narodowej, faktycznie jeszcze znacznie dłużej - była agendą parafii, znajdującą się pod bezpośrednią opieką proboszcza oraz nadrzędnych władz kościelnych, które wytyczały linię rozwoju szkolnictwa podczas synodów zarówno prowincjonalnych, jak i diecezjalnych oraz przeprowadzały kontrolę, przede wszystkim podczas wizytacji kanonicznych. Zob. S. K. OlCZaK, Szkolnictwo parafialne w Wielkopolsce w XVII i XVIII wieku, Lublin 1978, s. 7.

${ }^{79}$ S. K. Olczak, Rola Kościoła w nauczaniu elementarnym w Polsce, Ateneum Kapłańskie 95(1980) z. 3, s. 400; por. D. Olszewski, Dzieje chrześcijaństwa w zarysie, Katowice 1982, s. 163.
} 
trudniali w nich odpowiednich nauczycieli. Do ich obowiązków należało nie tylko przekazywanie prawd wiary, ale także uczenie dzieci i młodzieży dobrych obyczajów. Nie tylko przekazywanie wiedzy religijnej, ale również wychowywanie młodego pokolenia do życia zgodnego z nauką Kościoła, jak to określił i podał Sobór Trydencki ${ }^{80}$.

Biskup Karnkowski - stwierdzał, że „szkoła jest tym miejscem, gdzie rozstrzyga się przyszłość Kościoła i Rzeczypospolitej. Dlatego w dobie zagrożenia reformacją uczniowie potrzebują nie tyle nauczycieli, co świadków, a szkoła winna być integralną częścią Kościoła"81. Stąd na stanowisko nauczyciela nie wolno było zatrudnić osoby podejrzanej o herezję i prowadzącej niemoralny tryb i styl życia. Biskup zarządzał, „że nikt nie może być kierownikiem szkoły parafialnej, jeśli nie będzie zatwierdzony przez niego lub jego oficjała”. Nadto przypominał i nakazywał nauczycielom, złożenie wyznania wiary, co stanowiło warunek konieczny do zatrudnienia w szkole, a także dobrego przykładu w dziedzinie moralności i pobożności. Nauczającym w szkołach polecał trzymać się wypróbowanych metod nauczania. Zwracał też uwagę, iż ważniejsze jest wyrobienie właściwej postawy wychowanka, niż ilość wiedzy, a więc formacja przed informacją. Powołując się na postanowienia synodu prowincjalnego synod zalecał posługiwanie się w szkołach parafialnych Katechizmem rzymskim ${ }^{82}$.

Odnowie duszpasterstwa i jego ożywieniu miało służyć postanowienie synodalne czyniące kapitułę katedralną odpowiedzialną za całość nauczania w mieście biskupim - Włocławku, wskazując na rolę szkoły katedralnej ${ }^{83}$. Kapituła sprawując troskę nad szkołą, głównie za pomocą kanonika scholastyka, stawiała wymagania wobec uczących, a było ich kilku: rektor, nazywany niekiedy magistrem, bakałarz, też niekiedy zwany magistrem i kantor. Rektor szkoły sam dobierał

\footnotetext{
${ }^{80}$ Acta synodi dioecesanae Wladislaviae anno 1568 per Stanislaum Karnkowski episcopum celebratae, Z. CHODYŃsKI, Statuta synodalia..., s. 72.

81 Tamże, s. 72.

${ }^{82}$ Tamże, s. 72-73.

${ }^{83}$ Tamże, s. 72-73; zob. W. KuJAwsKI, Włocławek $w$ czasach nowożytnych i jego dzieje kościelne, w: Włocławek. Dzieje miasta (pod red. J. Staszewskiego), t. I, Włocławek 1999, s. 248.
} 
i opłacał współpracowników i odpowiadał za szkołę. Należy dodać, że za czasów biskupa Karnkowskiego szkoła katedralna przeżywała swój złoty okres ${ }^{84}$.

\section{Sprawowanie i przyjmowanie sakramentów św.}

Sprawowanie i przyjmowanie sakramentów św. stanowiło i nadal stanowi bardzo istotny nurt życia religijnego Kościoła lokalnego, stanowiący wymowne kryterium zarówno zaangażowania duszpasterskiego kapłanów, jak i chrześcijańskiej aktywności wiernych. Tym samym tematyka sakramentów posiadała - według biskupa Karnkowskiego - doniosły wpływ na odnowę duszpasterstwa. Dlatego w swoich uchwałach synodalnych wiele miejsca poświęcał zagadnieniom związanych z sakramentami. Całą grupę statutów regulującym te kwestie można podzielić na postanowienia ogólne i regulacje odnoszące się do poszczególnych sakramentów.

Jeżeli chodzi o postanowienia ogólne, to podejmują je obydwa synody diecezjalne. Już pierwszy odbyty w $1568 \mathrm{r}$. w tytule $D e$ parochorum offici, et aliorum curam animarum habentium dobitnie przypominał proboszczom i wikariuszom, że są zobowiązani do udzielania swoim parafianom sakramentów, które są środkami uświęcania. Winni to czynić z godnością i najwyższą pobożnością oraz w stanie łaski uświęcającej, albowiem „rzeczy święte ze świętością powinny być traktowane" ${ }^{\text {85 }}$. W stanie grzechu ciężkiego mogli kapłani udzielać sakramentów tylko jedynie w wypadku konieczności, ale musieli mieć zamiar jak najszybszego przystąpienia do spowiedzi. Szafarze sakramentów powinni znać dokładnie ich formę, wyrażoną w słowach i stosować właściwą dla poszczególnych sakramentów materię. Udzielając sakramentów powinni w tym momencie mieć także intencję czynienia tego, co czyni lub każe czynić Kościół. Jeśli nie mają tej intencji - stwierdzał synod - to nieważnie udzielają sakramentów. Nadto prawodawca synodalny nakazywał duszpasterzom, aby

\footnotetext{
${ }^{84}$ W. KUJAwsKi, Włocławek $w$ czasach nowożytnych..., s. 248-249.

${ }^{85}$ Acta synodi dioecesanae Wladislaviae anno 1568 per Stanislaum Karnkowski celebratae, Z. CHodý́ski, Statuta synodalia..., s. 58.
} 
przy udzielaniu sakramentów korzystali z księgi rytów kościelnych, „szczegółowo przestrzegając tego co napisane, żadnych czynności nie pomijając, aby niczego nie brakowało co odnosi się do poszczególnych tajemnic". Lekceważenie przepisów liturgicznych - zdaniem biskupa - powodowało zaciąganie przez szafarzy grzechu ciężkiego ${ }^{86}$.

W tytule szóstym części drugiej tego samego synodu, zatytułowanym De sacro chrismae et aquae, aliarumque rerum ecclesiastica benedictione prawodawca określił normy odnoszące się do olejów świętych. Były one - jak informował biskup - konsekrowane przez niego osobiście lub przez jego sufragana, co roku w katedrze włocławskiej i w innej świątyni przez biskupa wybranej. Mieli je z kościołów gdzie były poświęcone, odbierać archidiakoni i dziekani, a od nich poszczególni proboszczowie dla swoich kościołów parafialnych. Synod zabraniał odbierania olejów świętych przez osoby świeckie. Jednocześnie archidiakonom i dziekanom zakazano pobierania opłat za dystrybucję olejów. Tam gdzie były sprowadzone nowe oleje święte, prawodawca synodalny zabraniał używania olejów starych, wyjaśniając rządcom kościołów, że powinny one być „spalone, a zebrane popioły proboszcz winien umieścić pod ołtarzem, albo w urnie. Nie godzi się bowiem, aby były nikczemnie porzucone lub deptane stopami"87. W następnym synodzie z roku 1579 biskup Karnkowski raz jeszcze przypominał wcześniejsze regulacje co do udzielania sakramentów, zwracając uwagę na obowiązek posiadania księgi udzielania sakramentów. Ogólnie też zalecał duszpasterzom, aby zachęcali wiernych do częstego przyjmowania sakramentów, a w sposób szczególny sakramentu pokuty i Eucharystii ${ }^{88}$.

Powyższe normy ogólne dotyczące udzielania i przyjmowania sakramentów wpisywały się w troskę o jasne sprecyzowanie przepisów w tym względzie. Było to dyktowane zachowaniami wielu szafarzy dopuszczających się licznych nadużyć, jak też wielką troską o dobro

\footnotetext{
${ }^{86}$ Tamże.

87 Tamże, s. 66-67.

${ }^{88}$ Secunda synodus dioecesana Stanislai Karnkowski, Wladislaviae Anno Domini 1579 celebrata. Z. Chodý́ski, Statuta synodalia..., s. 82.
} 
wiernych i ich zbawienie. Jednocześnie były one pewnego rodzaju wstępem do szczegółowych ustaleń i wskazań prawnych co do poszczególnych sakramentów oraz ważnym etapem prowadzącym do zaangażowania duszpasterskiego duchowieństwa, jak i aktywności religijnej wiernych.

Regulacje odnoszące się do sakramentu chrztu znajdujemy głównie w statutach synodu z 1568 r., w tytule De baptismi administratione. Biskup Karnkowski, odwołując się do uchwał Soboru Trydenckiego ${ }^{89}$, najpierw bardzo szczegółowo wyjaśniał rolę i znaczenie tego sakramentu dla życia każdego człowieka, po czym wskazywał, że chrztu należy udzielać wyłącznie w świątyniach. Przepis ten miał zapewne na uwadze wykorzenienie praktyki sprawowania tego sakramentu - poza wypadkami konieczności - w domach. Jedynie w niebezpieczeństwie śmierci dziecka, dodawał statut, wolno było udzielać chrztu w domu. $\mathrm{W}$ związku z tym proboszczowie winni często pouczać parafian, iż w takim przypadku ważnie może ochrzcić nie tylko kapłan, lecz również osoba świecka, nie wyłączając heretyków, byle tylko posłużono się właściwą materią sakramentalną oraz przepisaną formą. Jeśli zaś niebezpieczeństwo śmierci minęłoby, należało przynieść dziecko do kościoła celem uzupełnienia ceremonii chrzcielnych. Sakrament chrztu powinien być sprawowany z największą troskliwością, dlatego prawodawca synodalny nakazywał, aby proboszczowie otoczyli troską wodę chrzcielną. Nie powinno się jej używać dopóty, dopóki proboszcz nie domiesza do niej oleju Krzyżma świętego. Zabroniono jednocześnie używania do chrztu wody, która miałaby widoczne zanieczyszczenia, a także nakazano, by do wody chrzcielnej nie miały dostępu osoby świeckie. Nad przestrzeganiem tych przepisów mieli czuwać archidiakoni ${ }^{90}$.

Na swoim drugim synodzie biskup Karnkowski wzywał do przestrzegania uchwał synodalnych z 1568 r., jednocześnie przypominając wcześniejsze zarządzenia co do obowiązku prowadzenia księgi

\footnotetext{
${ }^{89}$ Conc. Trid., sess. VII, c. 1-14 de bapt. oraz sess. XXIV, c. 2 de ref.

${ }^{90}$ Acta synodi dioecesanae Wladislaviae anno 1568 per Stanislaum Karnkowski episcopum celebratae, Z. CHody Ński, Statuta synodalia..., s. 58-59.
} 
ochrzczonych przy każdym kościele parafialnym oraz nie udzielaniu chrztu tym osobom, które były ochrzczone przez heretyków według formy przekazanej przez Chrystusa. Takie osoby powinny być tylko włączone do Kościoła. Jeżeli natomiast nie były w czasie chrztu namaszczone Krzyżmem świętym, namaszczenie to biskup zarezerwował sobie lub swoim sufraganom podczas sakramentu bierzmowania ${ }^{91}$.

Sakrament bierzmowania był regulowany na obydwu synodach przy okazji stanowienia przepisów odnośnie szafowania sakramentu chrztu. W statutach synodalnych z 1568 r., w artykule De baptismi administratione zobowiązywał proboszczów, by zatroszczyli się w swoich parafian i pouczali ich o doniosłości i pożytku z przyjęcia sakramentu bierzmowania. Wyjaśniał nadto, powołując się na naukę Tridentinum, że podobnie jak przy chrzcie zachodzi pokrewieństwo duchowe, tak też przy sakramencie bierzmowania zachodzi takie pokrewieństwo pomiędzy wybranym świadkiem bierzmowania, a przyjmującym sakrament oraz między świadkiem a rodzicami bierzmowanego. Ponieważ pokrewieństwo duchowe stanowiło przeszkodę do zawarcia małżeństwa, synod zobowiązywał duszpasterzy, aby wyjaśniali to wiernym, aby w ten sposób unikali nieważnego zawierania małżeństw ${ }^{92}$. Na synodzie następnym biskup Karnkowski nie regulował wprost prawnie i duszpastersko tego sakramentu lecz jedynie wspominając o chrzcie udzielanym przez innowierców stwierdzał: „ochrzczeni przez heretyków według formy przekazanej przez Chrystusa nie powinni być drugi raz ochrzczeni lecz jedynie włączeni ponownie do Kościoła. Jeżeli nie byli namaszczeni Krzyżmem świętym, to ich nie namaszczać, aż do czasu, gdy będą przez nas bierzmowani" ${ }^{\prime 93}$.

\footnotetext{
${ }^{91}$ Secunda synodus dioecesana Stanislai Karnkowski, Wladislaviae Anno Domini 1579 celebrata, Z. CHodyŃski, Statuta synodalia..., s. 83.

${ }^{92}$ Acta synodi dioecesanae Wladislaviae anno 1568 per Stanislaum Karnkowski episcopum celebratae. Z. CHODYŃski, Statuta synodalia..., s. 59.

${ }_{93}$ Secunda synodus dioecesana Stanislai Karnkowski, Wladislaviae Anno Domini 1579 celebrata, Z. CHodyński, Statuta synodalia..., s. 83.
} 
W uchwałach synodalnych znajdujemy wiele regulacji o charakterze duszpasterskim w odniesieniu do sakramentu Eucharystii. Otwiera je artykuł De Missa et Eucharistia synody z 1568 r. Biskup Karnkowski, powołując się na naukę Soboru Trydenckiego, omawiał w nim treści związane z sakramentem Eucharystii, podkreślał doniosłość tego sakramentu jako środka uświęcenia, a także zwracał uwagę na wielkość i znaczenie Mszy św., na jej istotę, charakter, skutki oraz przepisy liturgiczne ${ }^{94}$.

Prawodawca synodalny polecał odprawianie Mszy świętej tylko w kościołach lub kaplicach poświęconych, mających konsekrowany ołtarz, o czystym wnętrzu, wystroju i oświetleniu, zakazywał natomiast sprawowania Eucharystii w mieszkaniach prywatnych. Nakazywał, aby we wszystkich kościołach diecezji posługiwano się do sprawowania Eucharystii mszałem, zatwierdzonym przez Piusa $\mathrm{V}^{95}$. Kanon mszalny statuty nakazywały recy tować po cichu, zaś pozostałe części głośno, „tak by lud mógł je słyszeć i uczestniczyć we wspólnej modlitwie". Jednocześnie szczegółowo instruowano kapłanów o przebiegu liturgii Mszy świętej, zobowiązując do przestrzegania przepisów określonych w Mszale Rzymskim. Statut zobowiązywał celebransa przed wyjściem do ołtarza, aby upewnił się czy na ołtarzu znajduje się mszał, wino, woda, krzyż i czy są zapalone świece. Następnie powinien on sprawdzić czy w kościele nie ma osób ekskomunikowanych bądź jawnych przestępców, których należałoby poprosić o opuszczenie kościoła. Kapłani odprawiający Mszę świętą mieli używać przepisanych postaci eucharystycznych, pilnować materii i formy, czystości bielizny kościelnej (korporałów, puryfikaterzy, palek, obrusów ołtarzowych), posługiwać się własnymi szatami liturgicznymi, byli zobowiązani do zachowania postu eucharystycznego, a także czystości sumienia. W wypadku niedyspozycji duchowej najpierw

\footnotetext{
${ }^{94}$ Tamże, s. 83-84.

${ }^{95}$ Sobór Trydencki przedstawił swoją naukę na temat Mszy świętej w dekrecie Doctrina de Sacrificio Missae. Zob. Conc. Trid., sess. XXII, c. 1-9 de sacr. miss.; zob. W. GóRALSKI, Reformistyczne synody płockie na przełomie XVI i XVII wieku, Płock 1983, s. 46.
} 
powinni przystąpić do spowiedzi, a dopiero potem mogli sprawować Najświętszą Ofiarę ${ }^{96}$.

Statuty zabraniały celebrowania Mszy świętej przez kapłanów będących w karze ekskomuniki, suspensy oraz w miejscach, gdzie obowiązywała kara interdyktu, a także tym którzy „byli niegodni jej sprawowania, a których dyscyplina kościelna nakazywała trzymać z dala od świętych czynności Kościoła"97. Celebrans powinien jeszcze przed odprawieniem Mszy świętej odmówić godziny kanoniczne aż do prymy. Zabroniono odprawiać Mszy w intencjach: za rzeczy odzyskane z kradzieży, o wyzdrowienie chorego bydła albo za innego tego rodzaju sprawy, które wydają się nie być dalekie od zabobonu. Kapłanom - w myśl postanowień synodalnych - nie wolno było stawiać jakichkolwiek warunków dotyczących celebrowania Mszy świętej. Prawodawca dopuszczał jedynie przyjmowanie od wiernych dobrowolnych ofiar. Nadto, pod karą suspensy synod zabronił kapłanom dokonywania jakichkolwiek zmian w treści Mszy święteje ${ }^{98}$. Prawodawca synodalny zabronił także nowo wyświęconym kapłanom zbierania ofiar z okazji Mszy prymicyjnej i urządzania wystawnych przyjęć z tej okazji, tańców i pijatyk. Za złamanie tego zakazu groziły sankcje karne określone przez biskupa ${ }^{99}$. W postanowieniach tego artykułu znajdujemy również polecenie, aby proboszczowie pouczali swoich parafian, że są zobowiązani do udziału we Mszy świętej we wszystkie niedziele i święta ${ }^{100}$.

Powyższe regulacje zostały skrótowo ponowione w synodzie $\mathrm{z} 1579 \mathrm{r}^{101} \mathrm{~W}$ ten sposób po tak dokładnym przedstawieniu zagadnień dogmatyczno - prawnych, liturgicznych i duszpasterskich odnośnie sprawowania Mszy świętej przez oba synody Karnkowskiego, powstał

\footnotetext{
${ }^{96}$ Acta synodi dioecesanae Wladislaviae anno 1568 per Stanislaum Karnkowski episcopum celebratae, Z. CHodyŃski, Statuta synodalia..., s. 60-61.

${ }^{97}$ Tamże, s. 60.

98 Tamże, s. 61.

${ }^{99}$ Tamże, s. 62.

${ }^{100}$ Tamże.

${ }^{101}$ Secunda synodus dioecesana Stanislai Karnkowski, Wladislaviae Anno Domini 1579 celebrata, Z. CHodyński, Statuta synodalia..., s. 83.
} 
w diecezji właściwy grunt i klimat wprowadzania reformy i odnowy duszpasterstwa, w myśl dekretów Tridentinum. Nie było to jednak takie łatwe i proste, gdyż trzeba było pokonać złe przyzwyczajenia i nawyki duchowieństwa, zaniedbania, brak należytej wiedzy i niechęci do tego co nowe.

Dyspozycje odnośnie Komunii świętej znajdujemy w obszernym artykule drugim, części drugiej synodu biskupa Karnkowskiego z roku 1568, zatytułowanym De Missa et Eucharistia. Prawodawca synodalny ukazując doniosłość Komunii świętej, jako środka uświęcenia i zbawienia stwierdzał, że jej przyjmowanie wymaga wiary, właściwego duchowego przygotowania oraz odbycia spowiedzi, jeżeli wierny obciążony jest grzechami ciężkimi, bowiem „sakrament Ciała i Krwi Pańskiej wymaga, aby przystępujący do niego był czysty w tym momencie od brudów grzechów ciężkich"102. Wprowadzenie tej dyspozycji w życie i postępowanie wiernych wymagało - jak nakazywał prawodawca - pouczania i wychowywania wiernych w zakresie właściwego przygotowania się do przyjmowania Komunii świętej, a więc gorliwej pracy duszpasterskiej. Mieli to czynić proboszczowie poprzez głoszenie odpowiednich kazań i jak i w trakcie nauczania katechetycznego wiernych. Nadto synod zobowiązywał duszpasterzy do zachęcania wiernych do jak najczęstszego przystępowania do Komunii świętej, ,a nie tylko raz w roku, jak to jest w zwyczaju ludzi leniwych i niegodziwych"103.

\footnotetext{
${ }^{102}$ Acta synodi dioecesanae Wladislaviae anno 1568 per Stanislaum Karnkowski episcopum celebratae, Z. CHOdyński, Statuta synodalia..., s. 61-62. Potrzebę przygotowania się, odpowiednich dyspozycji wewnętrznych i zewnętrznych i pożytku z godnego przyjęcia Komunii świętej wyjaśniał szczegółowo Katechizm Rzymski (Trydencki) przetłumaczony na język polski przez biskupa Karnkowskiego już jako arcybiskupa gnieźnieńskiego. Zob. Katechizm Rzymski z dekretu S. Koncilium Trydenckiego za rozkazem s. Piusa V Papieża po łacinie wydany, na polski język powaga [...] Ks. Stanisława Karnkowskiego, arcybiskupa Gnieźnieńskiego, prymasa przez pytania i odpowiedzi przetlumaczony [...] Ks. Felicjanowi Wołodkowiczowi arcybiskupowi metropolicie Kijowskiemu [...] oraz biskupom i duchowieństwu ritus Greco-unito [...] wydrukowany w Wilnie 1762 roku, Wilno 1762, s. 129-134.

${ }^{103}$ Acta synodi dioecesanae Wladislaviae anno 1568 per Stanislaum Karnkowski episcopum celebratae, Z. CHodyŃski, Statuta synodalia..., s. 62.
} 
W trosce o chorych i będących w niebezpieczeństwie śmierci biskup Karnkowski, polecał proboszczom, aby w kazaniach przypominali o stosowności i pożytku przyjmowania Komunii świętej w formie wiatyku. Jednocześnie synod określał dość krótko, sposób i formę zanoszenia Komunii świętej do chorych i umierających. Otóż należało wiatyk zanosić procesjonalnie, przy udziale wiernych, czemu powinny towarzyszyć światła świec i dzwonki. Towarzyszący procesji do domu chorego, jak i oczekujący w domu chorego, mieli się modlić za chorego. Prawodawca podawał przy tej okazji - co warte jest zauważenia - wspaniałe teologiczne wyjaśnienie owej procesji z wiatykiem do domu chorego, pragnąc, aby była ona czytelnym znakiem wiary. Jednocześnie zachęcał proboszczów do działań duszpasterskich, aby te obrzędy pielęgnować i rozwijać ${ }^{104}$.

Ważnym zagadnieniem w Kościele w XVI wieku był sposób przyjmowania Komunii świętej. Stąd prawodawca synodalny zdecydowanie wypowiadał się za przyjmowaniem Komunii świętej pod postacią chleba i do takiego udzielania zobowiązywał kapłanów. Nakaz ten wiązał się ze sprawą Komunii świętej pod dwiema postaciami, która budziła wiele kontrowersji na przestrzeni historii Kościoła co do sposobu przyjmowania Eucharystii, a którą podjął i uregulował także Sobór Trydencki w dekrecie Sacrosancta ${ }^{105}$. Mając na uwadze silne wpływy protestantyzmu na terenie diecezji kujawskiej i pomorskiej oraz pragnąc usunąć wszelkie wątpliwości, powołując się na postanowienia Soboru Trydenckiego, biskup Karnkowski wyjaśniał i nakazywał duszpasterzom nauczać o tym wiernych, „iż przyjmując Komunię świętą pod postacią chleba przyjmują prawdziwy sakrament i całego Chrystusa i nie przyjmują mniejszego duchowego owocu, niż gdyby przyjmowali Go pod dwiema postaciami"106. Nakaz ten został

\footnotetext{
104 Tamże.

${ }^{105}$ Conc. Trid., sess. XIII, c. 1 et 3 de Sanc. Euch. sacr.; zob. J. Mielczarek, Komunia pod dwiema postaciami w ustawodawstwie Kościoła Zachodniego. Studium historyczno-prawne, Lublin 1983.

${ }^{106}$ Acta synodi dioecesanae Wladislaviae anno 1568 per Stanislaum Karnkowski episcopum celebratae, Z. CHOdYŃski, Statuta synodalia..., s. 62.
} 
w statutach bardzo mocno zaakcentowany stwierdzeniem biskupa, „że nauka Nauczycielskiego Urzędu Kościoła jest pewna i duchowni i wierni winni ją wypełniać, ci zaś którzy nie przyjmują Eucharystii nie mogą się nazywać chrześcijanami”107. Ponownie bardzo mocno sprawę Komunii świętej pod postacią chleba stawiał na synodzie w 1579 r. ${ }^{108}$

Oprócz tematyki dotyczącej Mszy świętej oraz Komunii świętej wiernych wiele miejsca synody biskupa Karnkowskiego poświęcały przechowywaniu i kultowi Najświętszego Sakramentu. Miało to na celu wykorzenienie istniejących w tej dziedzinie zaniedbań i uchybień i tym samym wzrost chwały Bożej, a także ożywienie duszpasterstwa eucharystycznego. Synod z 1568 r. we wspomnianym artykule De Missa et Eucharistia nakazywał „konsekrowane postacie przechowywać w czystym, ozdobnym i dobrze zabezpieczonym miejscu, na korporale, zasłonięte welonem, nie powinny być dłużej przechowywane niż czternaście dni ${ }^{109}$. Po spożyciu wcześniej konsekrowanych hostii proboszczowie mieli zachować wystarczającą ilość nowo konsekrowanych, aby zawsze Eucharystia była dostępna dla celów zanoszenia wiatyku. Prawodawca zobowiązywał, aby tam gdzie pozwalają na to warunki i możliwości, przed Najświętszym Sakramentem paliło się światło świecy lub lampki. Obowiązkowo światło powinno palić się w niedziele i święta, kiedy wierni gromadzili się na Mszę świętą, podczas nabożeństw i modlitwy brewiarzowej. Duszpasterze byli zobowiązani przez biskupa do pouczania wiernych odnośnie zachowania się w obecności i przed Najświętszym Sakramentem, a także mieli wzywać do adoracji wiernych i sami dawać jej przykład. Synod nakazywał coroczne obchodzenie święta Bożego Ciała poprzez „uroczyste przenoszenie Eucharystii w pochodzie ze czcią i pobożnością

\footnotetext{
${ }^{107}$ Tamże, s. 62

${ }^{108}$ Secunda synodus dioecesana Stanislai Karnkowski, Wladislaviae Anno Domini 1579 celebrata, Z. CHODyŃski, Statuta synodalia..., s. 83.

${ }^{109}$ Acta synodi dioecesanae Wladislaviae anno 1568 per Stanislaum Karnkowski episcopum celebratae, Z. CHodyŃski, Statuta synodalia..., s. 61.
} 
przeprowadzonym"110. Podobne dyspozycje znajdujemy w uchwałach synodu z 1579 r., aczkolwiek w formie bardzo skrótowej, z dobitnym zaznaczeniem, aby „wszyscy wierni odnosili się do Eucharystii z czcią i pobożnością, a wszyscy prałaci, kanonicy i inni wyższej rangi duchowni, mieli z najwyższym szacunkiem przyklękać na obydwa kolana przed Najświętszym Sakramentem"111.

W artykule De Poenitentia, synodu z 1568 r. biskup Karnkowski z kolei szeroko omawiał stronę teologiczną sakramentu pokuty, wyjaśniając jej znaczenie dla życia chrześcijanina. Stąd na duszpasterzy prawodawca nakładał obowiązek nauczania wiernych czym jest pokuta, jakie są jej części i w jaki sposób poszczególne elementy sakramentu pokuty należy wypełniać, by łaskę Bożą odzyskać. Zobowiązywał wiernych, którym wiek na to pozwalał, często korzystali z sakramentu pokuty - dwa razy w ciągu Wielkiego Postu, raz na jego początku, następnie przed przystąpieniem do Komunii przed Wielkanocą. Odstęp pomiędzy odbyciem spowiedzi, a przystąpieniem do Komunii świętej - zdaniem ustawodawcy synodalnego - był potrzebny, „aby wierni bardziej zrozumieli swoje grzechy i wartość Bożego przebaczenia, a oczyszczeni przez ten sakrament, łatwiej mogli przyjąć Komunię świętą z jej łaskami”"112.

Dalej w uchwałach synodalnych biskup Karnkowski omawiał, w celach duszpasterskich, warunki sakramentu pokuty: żal za grzechy, spowiedź i godne wypełnienie zadośćuczynienia. Wzywał proboszczów, aby studiowali dokumenty soborowe i Katechizm Rzymski, gdzie obszernie i jasno sakrament pokuty został omówiony. Biskup wymieniał grzechy i osoby jemu zarezerwowane do rozgrzeszenia: zabójstwa, uduszenie dzieci (infantium pressurae), ekskomunikowani, heretycy i tym podobne. Jeżeli jednak, stanowiły statuty, „byłaby przyczyna, wymagająca szybszego rozgrzeszenia, to nie mając pozwolenia

\footnotetext{
${ }^{110}$ Tamże, s. 61-62.

${ }^{111}$ Secunda Synodus Dioecesana Stanislai Karnkowski, Wladislaviae Anno Domini 1579 celebrata, Z. CHodyŃskI, Statuta synodalia..., s. 83.

${ }^{112}$ Acta Synodi Dioecesana Wladislaviae anno 1568 per Stanislaum Karnkowski episcopum celebratae, Z. CHODYŃski, Statuta synodalia...,s. 62.
} 
biskupiego, proboszcz mógł, sprawiedliwie osądziwszy sprawę, udzielić rozgrzeszenia”. Nie mógł jednak udzielić rozgrzeszenia wiernym, którzy nie przynależeli do jego parafii, z wyjątkiem pozwolenia ich proboszcza i konieczności ${ }^{113}$.

Biskup Karnkowski zaniepokojony ignorancją wiernych na temat pokuty oraz przystępowaniem do spowiedzi bardziej z przyzwyczajenia niż z wewnętrznej potrzeby, co odbijało się na jej szczerości, nakazywał proboszczom, by przez okres Adwentu i Wielkiego Postu często głosili kazania o sakramencie pokuty wyjaśniając co jest potrzebne, aby w pełni otrzymać łaski tego sakramentu. Celem podniesienia wiedzy religijnej wiernych, za powyższym zarządzeniem ustawodawcy synodalnego, szło następne, bardziej rygorystyczne. Otóż, podczas spowiedzi proboszcz był zobowiązany egzaminować wiernych ze znajomości: Ojcze nasz, Zdrowaś Maryjo, Wierzę w Boga, Dekalogu, a także z podstawowych prawd wiary. Tych, którzy nie znali pacierza i prawd wiary, należało douczyć, a jeśli do określonego czasu nie będą tego znać, należało wykluczyć od Komunii świętej ${ }^{14}$.

Te szerokie i szczegółowe wyjaśnienia prawno-duszpasterskie odnośnie sakramentu pokuty zostały raz jeszcze przypomniane, aczkolwiek skrótowo, na synodzie w 1579 r. Ustawodawca wzywał spowiedników do roztropności, znajomości rezerwatów papieskich i biskupich, sugerując, aby mieli je spisane. Zalecał szafarzom pokuty szczególną roztropność w tym względzie, odsyłanie w przypadku rezerwatów, do tych którzy mają władze rozgrzeszenia. Wyjaśniał, że kiedy nie ma u penitenta prawdziwego żalu za grzechy lub zobowiązania do restytucji, nie powinni spowiednicy udzielać rozgrzeszenia. Przypominał również, iż w przypadku grzechu śmiertelnego, bez spowiedzi nie należy dopuszczać do Komunii świętej ${ }^{115}$.

Synod z 1568 r. doceniając znaczenie sakramentu namaszczenia chorych w artykule szóstym De extrema Unctione, skierował do

\footnotetext{
${ }^{113}$ Tamże, s. 63.

114 Tamże.

${ }^{115}$ Secunda synodus dioecesana Stanislai Karnkowski, Wladislaviae Anno Domini 1579 celebrata, Z. CHodyńskI, Statuta synodalia..., s. 83.
} 
duszpasterzy, a w pierwszym rzędzie do proboszczów polecenie, aby udzielali namaszczenia wszystkim tym, którzy o to proszą. Zwrócił uwagę, by proboszczowie pouczali wiernych o zbawiennych skutkach namaszczenia chorych. Tego obowiązku nie powinni nigdy zaniedbywać. Wierni natomiast powinni zrozumieć, że sakrament ten niesie im pomoc w cierpieniu i chorobie. Statuty nakazywały duszpasterzom, by chętnie udawali się do chorych, nawet nie czekając na wezwanie przez rodzinę chorego i „niech udzielają im sakramentu Eucharystii i ostatniego namaszczenia; niech pozostaną przy umierającym i wspierają go pobożnymi modlitwami i świętymi napomnieniami, aby w prawdziwej wierze katolickiej oddali swego ducha Bogu"116. Ze szczególną troską powinni oni otoczyć w tym względzie ludzi ubogich, będących w chorobie. Szafowanie tego sakramentu - podkreślał biskup Karnkowski - proboszczowie mieli otoczyć najwyższą czcią, posługując się właściwym rytem zamieszczonym w przepisanych agendach ${ }^{117}$.

Synody biskupa Karnkowskiego, mając na uwadze potrzeby duszpasterskie diecezji zajmowały się również uregulowaniem przepisów dotyczących udzielania i przyjmowania sakramentu kapłaństwa, jak i właściwej formacji i przygotowania kandydatów do święceń. Sprawę formacji i przygotowania do kapłaństwa omówiono już w punkcie o seminariach włocławskich, gdzie wskazano wysiłki biskupa Karnkowskiego co do powstania i funkcjonowania seminarium duchownego we Włocławku. Należy jednak zaznaczyć, iż oprócz tego synody regulowały kwestie dyscyplinarne i prawne związane z samym przyjmowaniem święceń. Otóż synod z 1568 r. w artykule De Ordinandis, podkreślał doniosłość stanu kapłańskiego i troskę o to, ,aby święcenia kapłańskie przyjmowali kandydaci jak najbardziej wypróbowani w wierze i moralności". W tym celu przypominał duchowieństwu i wiernym o obowiązku modlitwy o powołania kapłańskie, a także za kandydatów do kapłaństwa, „by Bóg udzielał

\footnotetext{
${ }^{116}$ Acta synodi dioecesanae Wladislaviae anno 1568 per Stanislaum Karnkowski episcopum celebratae, Z. CHоDYŃsкi, Statuta synodalia..., s. 63. ${ }^{117}$ Tamże.
} 
im łaski w celu spełniania swego obowiązku godnie i z pożytkiem dla wiernych oraz by przynosili obfity owoc swego kapłańskiego życia”. W trosce o coraz to nowych aspirantów do święceń prawodawca kładł na barki proboszczów pieczę i odpowiedzialność w dziedzinie budzenia i kształtowania powołań kapłańskich. Jednocześnie proboszczowie mieli otoczyć szczególną opieką kandydatów, którzy przyjęli już święcenia niższe, zaprawiając ich w poznawaniu dyscyplin kościelnych. Zobowiązywał nadto kandydatów do kapłaństwa do takiego poziomu życia, który będzie przewyższał poziom życia duchowego zwykłych wiernych. Kandydaci ci wybierając drogę kapłaństwa powinni pamiętać, że do realizacji tego celu nie wystarczy sama dobra wola, ale potrzebna jest przede wszystkim łaska powołania kapłańskiego. Biskup Karnkowski nakazywał proboszczom, co stanowiło pewien priorytet duszpasterski, troskę o powołania kapłańskie oraz wychowanie i wykształcenie kandydatów do stanu kapłańskiego ${ }^{118}$.

Prawodawca zobowiązywał kandydata do kapłaństwa, by na miesiąc przed święceniami, które najczęściej były udzielane pod koniec Wielkiego Postu, zgłosił się do proboszcza, któremu podlegał i oznajmił wolę przyjęcia święceń kapłańskich. Kaznodzieje w katedrze i proboszczowie we wszystkich kościołach kolegiackich, zakonnych i parafialnych byli zobowiązany ogłaszać ich nazwiska wiernym i od nich zasięgnąć opinii o kandydacie, a następnie powiadomić biskupa ordynariusza lub sufragana. Wierni mieli swój udział w dopuszczaniu do święceń na podstawie istniejącego w diecezji zwyczaju, który dopuszczał ich do wystawiania kandydatom do kapłaństwa opinii i świadectwa. Po wygłoszeniu nazwiska kandydata do święceń - zgodnie $\mathrm{z}$ wolą ustawodawcy - miał on zdać egzamin przed prefektem. Po zdaniu dwudniowego egzaminu $\mathrm{z}$ kandydatem przeprowadzał rozmowę biskup i wyznaczał proboszcza, tzw. egzaminatora, który przeprowadzał badanie kanoniczne, tj. sprawdził tożsamość i wiek

${ }^{118}$ Acta Synodi Dioecesanae Wladislaviae anno 1568 per Stanislaum Karnkowski episcopum celebratae, Z. CHodý́ski, Statuta synodalia..., s. 53. Artykuł synodu powoływał się na naukę Tridentinum, analizował ją i przypominał. Zob. Conc. Trid., sess. XXIII, c. 5, 7, 13, 14, 16 de ref. 
kandydata oraz świadectwo życia i wiedzy od nauczyciela kandydata, pochodzenie, obyczaje, zasięgnął opinii wiarygodnych świadków, wygłosił zapowiedzi. Wyniki tych badań należało jak najszybciej złożyć w urzędzie biskupim. Również wszyscy kapłani byli zobowiązani do zaopiniowania kandydatów do święceń ${ }^{119}$.

Ważną rolę w dopuszczaniu kandydatów do święceń mieli egzaminatorzy, synod z 1568 r. w tytułach: De Officio Examinatoris, De impedimeno Ordinandorum oraz De provisionibus institutionibus, szczegółowo wyjaśniał rolę i obowiązki egzaminatorów. Ich zadaniem było przede wszystkim „egzaminowanie przyszłych proboszczów, a także dokładne badanie wieku, wiedzy i życia tych, którzy mieli przyjąć święcenia”. Mieli dokładnie wypytać kandydata o tytuł do święceń, zwrócić uwagę czy jest ugruntowany w zdrowej nauce Kościoła, zorientować się co do czystości intencji przyjęcia święceń, a także spoczywał na nich obowiązek zbadania czy znali naukę Kościoła, czy nie myśleli po heretycku i nie byli apostatami, opętanymi przez złego ducha, czy byli wykształceni w naukach humanistycznych, czy nie byli nieślubnym dzieckiem, czy nie mieli jakichś znaczących ułomności cielesnych, wad moralnych, czy chorób (padaczki), czy nie posiadali złej opinii lub nie byli ekskomunikowani, a także czy byli wolni od symonii, zniesławienia i niezrównoważenia ${ }^{120}$. Nadto, zgodnie z wolą ustawodawcy synodalnego, egzaminatorzy mieli badać czy kandydat do święceń jest zdolny wypełniać obowiązki duszpasterskie. $\mathrm{W}$ wypadkach trudnych i budzących jakieś wątpliwości czy zastrzeżenia co do kandydata do święceń, biskup rezerwował sobie, albo swemu wikariuszowi, prawo zakończenia badania kanonicznego i wydania decyzji. Ponadto egzaminatorzy mieli zwracać uwagę na to, że tylko biskup diecezjalny jest właściwym biskupem upoważnionym do udzielania święceń. Domagał się także biskup, aby kapłan prędzej nie otrzymał beneficjum, dopóki przez niego lub przez osobę przez

\footnotetext{
${ }^{119}$ Acta Synodi Dioecesanae Wladislaviae anno 1568 per Stanislaum Karnkowski episcopum celebratae, Z. CHODYŃski, Statuta synodalia..., s. 53.

${ }^{120}$ Tamże, s. 53-54.
} 
niego delegowaną nie zostanie uważnie przebadany ${ }^{121}$. Jednocześnie biskup, za Soborem Trydenckim ${ }^{122}$, podawał właściwy wiek do poszczególnych święceń: 22 lata do subdiakonatu, 23 do diakonatu i 25 do prezbiteratu. Zarządzenie to dotyczyło również zakonników ${ }^{123}$.

Statuty synodu z 1568 r. przedstawiały także w artykule ósmym zatytułowanym Simoniae vitio quemadmodum occurrant bolesną sprawę symonii, którą określały i uznawały za grzech śmiertelny. Prawodawca zarządzał w tym względzie, aby przed każdym stopniem święceń i przyjęciem urzędu probostwa składano wobec biskupa lub jego wikariusza przysięgę, że kandydat jest od tego grzechu wolny. Po omówieniu tego wykroczenia, statut synodalny określał formę przysięgi na okoliczność wolności od symonii ${ }^{124}$.

Uchwały synodalne, powołując się na soborowy dekret Tametsi ${ }^{125}$, podawały również dyspozycje dotyczące sakramentu małżeństwa. Artykuł zatytułowany De Matrimonio et eius forma, bardzo dokładnie i szczegółowo omówił ten sakrament. Najpierw in extenso przytoczył dekret Soboru o małżeństwie, a potem go wyjaśniał. Biskup Karnkowski pouczał wiernych o obowiązku zawierania małżeństwa zgodnie z przepisaną przez Sobór i synod formą. Zalecał duszpasterzom i kaznodziejom, aby statut synodu dotyczący zawierania małżeństwa odczytywali w kościołach i wyjaśniali go wiernym; w pierwszym roku po synodzie jak najczęściej, a później, ilekroć będzie to konieczne. Orzekał, że statut ten nabiera mocy prawa w każdej parafii po trzydziestu dniach od ogłoszenia go w danej parafii. Zobowiązywał, aby gorliwie, pobożnie i zgodnie z przepisami liturgicznymi błogosławili małżeństwa i wykazywali troskę, by narzeczeni dokładnie wypowiadali słowa formy zarówno zaręczyn, jak i małżeństwa. Synod, w imię dobra rodziny chrześcijańskiej, stanowczo zakazywał i zabraniał

\footnotetext{
${ }^{121}$ Tamże, s. 54

${ }^{122}$ Conc. Trid., sess. XXIII, c. 12 de ref.

${ }^{123}$ Zob. Conc. Trid., sess. XXI, c. 2 de ref.; Acta synodi dioecesanae Wladislaviae anno 1568 per Stanislaum Karnkowski episcopum celebratae, Z. CHODYŃsKI, Statuta synodalia...,s. 54-55.

${ }^{124}$ Tamże, s. 55.

${ }^{125}$ Conc. Trid., sess. XXIV, c. 1-10 de ref. matrim.
} 
zawierania małżeństw tajnych i wyznaniowo mieszanych ${ }^{126}$. Nadto przypominał duszpasterzom o obowiązku wygłaszania przed zawarciem małżeństwa zapowiedzi, których celem było wykrycie ewentualnych przeszkód małżeńskich. Zapowiedzi należało wygłosić w kościele parafialnym w ciągu trzech kolejnych dni świątecznych. Dyspensę od zapowiedzi zastrzegał sobie sam biskup. Jednocześnie wyjaśniał, że małżeństwo zawierane bez udziału proboszcza lub innego kapłana mającego zgodę tego proboszcza lub biskupa i dwóch lub trzech świadków, jest nieważne. Chcąc położyć kres nadużyciom w tym względzie, a związanym z tzw. zwyczajem niepamiętnym lub przywilejem osobistym upoważniającym do błogosławienia małżeństw z pominięciem tego zakazu, pod groźbą suspensy, prawodawca zakazywał błogosławienia małżeństw kapłanom posiadającym wyżej wspomniany przywilej bez zgody proboszcza miejsca. Od kary zaciągniętej w ten sposób duchowny mógł być uwolniony jedynie przez ordynariusza, którego jurysdykcji podlegał proboszcz, który powinien błogosławić małżeństwo ${ }^{127}$.

Powołując się na uchwały trydenckie i zasadę ius parochiale, synod zakazał proboszczom pod karą suspensy sprawowania tego sakramentu wobec osób spoza parafii, chyba że wcześniej otrzymali zgodę od ich proboszcza. Do obowiązków proboszcza należało wyjaśnić i pouczyć nupturientów o skutkach, prawach i obowiązkach małżeńskich wynikających z Pisma Świętego i nauki Kościoła; przeprowadzić badanie kanoniczne narzeczonych, a więc ustalić ich stan wolny, sprawdzić czy nie zachodzą między narzeczonymi przeszkody małżeńskie, a także czy znają Ojcze nasz, Pozdrowienie Anielskie, Skład Apostolski i Dekalog. Byli zobowiązani pouczyć również narzeczonych, by przynajmniej na trzy dni przed zawarciem małżeństwa, odbyli spowiedź i przyjęli Komunię świętą. Proboszczowie byli zobowiązani do starannego prowadzenia ksiąg zaślubionych, w której powinny być odnotowane nazwiska małżonków i świadków, a także

\footnotetext{
${ }^{126}$ Acta Synodi Dioecesanae Wladislaviae anno 1568 per Stanislaum Karnkowski episcopum celebratae, Z. CHODYŃski, Statuta synodalia..., s. 64-65.

${ }^{127}$ Tamże, s. 65.
} 
data i miejsce ślubu ${ }^{128}$. Biskup Karnkowski nadto ostrzegał duszpasterzy przed bigamią. Proboszczowie podczas badania kanonicznego byli zobowiązani dokładnie sprawdzić stan wolny nupturientów, szczególnie odnosiło się to do osób pochodzących z innej parafii i bezdomnych. Synod zakazywał błogosławienia małżeństw osób wyżej wymienionych bez zezwolenia ordynariusza. Nadto proboszczowie mieli obowiązek wyjaśniać wiernym zakres pokrewieństwa duchowego, powstającego wskutek chrztu i bierzmowania, a także o przeszkodzie małżeńskiej powinowactwa, występującej na skutek pozamałżeńskiego współżycia seksualnego, która obowiązywała do drugiego stopnia włącznie. Przypomniano również, że nie wolno błogosławić małżeństw w czasach zakazanych, tj. w okresie od pierwszej niedzieli Adwentu do Trzech Króli oraz od Środy Popielcowej do oktawy Wielkanocy włącznie ${ }^{129}$.

Przytoczone wyżej szczegółowe przepisy co do zawierania małżeństwa zostały bardzo krótko przypomniane raz jeszcze na drugim synodzie diecezjalnym biskupa Karnkowskiego z 1579 r., gdzie prawodawca synodalny ponownie uwagę zwrócił na kanoniczne badanie przedślubne, przeszkody do zawarcia małżeństwa, formę zawarcia małżeństwa oraz prowadzenie przez proboszczów księgi zaślubionych ${ }^{130}$.

\section{Pozostałe akty kultu Bożego, miejsca i czasy święte oraz sprawy liturgiczne}

Ważnym elementem odnowy duszpasterstwa były również regulacje odnoszące się do pozostałych aktów kultu Bożego, miejsc i czasów świętych oraz spraw liturgicznych. Stanowione normy i zarządzenia synodalne biskupa Karnkowskiego, inspirowane odnową trydencką, miały wpływ na kształt duszpasterstwa w diecezji, określały

\footnotetext{
128 Tamże, s. 65-66.

129 Tamże, s. 66.

${ }^{130}$ Secunda Synodus Dioecesana Stanislai Karnkowski, Wladislaviae Anno Domini 1579 celebrata, Z. Chodý́ski, Statuta synodalia..., s. 83.
} 
sprawowanie innych form kultu Bożego i sakramentaliów, zapobiegały nadużyciom oraz odnawiały i ujednolicały liturgię.

Jednym z poważniejszych problemów diecezji kujawskiej i pomorskiej w okresie potrydenckim był znaczny brak mszałów, brewiarzy i innych ksiąg liturgicznych, które zgodnie z dekretem soboru Trydenckiego ${ }^{131}$ oraz dekretem synodu prowincjalnego piotrkowskiego $\mathrm{z} 1577 \mathrm{r}^{132}$, powinny być używane w czasie liturgii. W tym celu biskup Karnkowski, zarówno na synodzie w 1568 jak i 1579 r., zobowiązywał duchowieństwo do nabywania nowego Mszału Rzymskiego, Katechizmu i brewiarza ${ }^{133}$.

Właściwemu sprawowaniu - w jednolity sposób - szeroko rozumianej liturgii miały służyć, zdaniem prawodawcy synodalnego, jeszcze inne księgi, których posiadanie obowiązywało kościoły parafialne. Zaliczono do nich: agendę liturgiczną, wągrowicki wykład Ewangelii (postyllę), czyli zbiór homilii, uchwały Soboru Trydenckiego, statuty prowincjalne i diecezjalne. Biskup Karnkowski, polecając zaopatrzenie się przez proboszczów w wymienione księgi, zarządził, aby ściśle stosowano się do zawartych w nich rubryk i przepisów zarówno w odmawianiu modlitw, jak i w sprawowaniu Mszy świętej i sakramentów, wykładzie nauki katolickiej oraz w wykonywaniu śpiewu. W ten sposób miało nastąpić tak pożądane przez biskupa ujednolicenie w całej diecezji sprawowania liturgii i kultu Bożego ${ }^{134}$.

Temu celowi, a także w trosce o liturgię Karnkowski napisał Napomnienia potrzebne i zbawienne, których wszyscy plebani w Kujawskim i Pomorskim biskupstwie przy świętości kościelnych sprawować mają...,

\footnotetext{
${ }^{131}$ Conc. Trid., sess. XXV de ind. libr.

${ }^{132}$ Synod arcybiskupa Jakuba Uchańskiego odbyty w Piotrkowie w 1577 r., w artykule 22 nakazywał używanie Mszału Rzymskiego i brewiarza zatwierdzonego przez Sobór Trydencki. Zob. I. Suber A, Synody prowincjonalne..., s. 249.

${ }^{133}$ Acta synodi dioecesanae Wladislaviae anno 1568 per Stanislaum Karnkowski episcopum celebratae, Z. CHODYŃsKi, Statuta synodalia..., s. 57-58; Secunda synodus dioecesana Stanislai Karnkowski, Wladislaviae Anno Domini 1579 celebrata. Tamże, s. $82-83$.

${ }^{134}$ Secunda synodus dioecesana Stanislai Karnkowski, Wladislaviae Anno Domini 1579 celebrata, Z. CHodý́ski, Statuta synodalia..., s. 82-83.
} 
które wydane zostały przez Szarffenberga w Krakowie w 1568 r. ${ }^{135}$ Książeczka ta została napisana w języku polskim i doczekała się w przeciągu krótkiego okresu czasu kilku wydań ${ }^{136}$.

Należy również podkreślić, że biskup Karnkowski rozumiejąc potrzebę ujednolicenia sprawowania kultu Bożego i liturgii w rozległej diecezji oraz wychodząc naprzeciw postulatom Tridentinum i odnowie duszpasterskiej diecezji, po swoim pierwszym synodzie odbytym w roku 1568 opracował agendę liturgiczną dla diecezji włocławskiej, którą wydał w 1572 r. w Kolonii u M. Cholina. Była ona zatytułowana: Adminitiones quinque circa sacramentorum administrationem faciendae... ${ }^{137}$ i przedstawiała naukę doktrynalną i praktyczną Kościoła o pięciu sakramentach (chrzcie, pokucie, Eucharystii, ostatnim namaszczeniu, małżeństwie). Karnkowski odresował ją do duchowieństwa diecezji włocławskiej celem pomocy w pracy duszpasterskiej ${ }^{138}$. Agenda ta decyzją synodu prowincjalnego piotrkowskiego z 1577 r. została ogłoszona za obowiązującą w metropolii gnieźnieńskiej i w 1578 r. została ponownie wydana po przystosowaniu jej do użytku kościołów całej prowincji gnieźnieńskiej przez ks. Tomasza Płazę ${ }^{139}$.

Odnowie duszpasterstwa służyły też uchwały synodalne regulujące pogrzeb chrześcijański. Odmawiały one pogrzebu i grzebania zmarłych na poświęconym miejscu na cmentarzu osobom ekskomunikowanym, niewiernym, heretykom, schizmatykom, imiennie

\footnotetext{
${ }^{135}$ S. KaRnKowsKi, Napomnienia potrzebne y zbawienne, których wszyscy plebani w Kuiawskim y Pomorskim Biskupstwie przy świętości kościelnych sprawowaniu używać maja, Kraków 1568 M. Szarffenberg.

${ }^{136}$ A. BRUŹDZIŃsKI, Wkład biskupa Stanisława Karnkowskiego $w$ dzieło recepcji reformy trydenckiej w diecezji kujawsko-pomorskiej, Kraków 1990 (mps Bibl. Sem. Duch. we Włoclawku), s. 148.

${ }^{137} \mathrm{~S}$. KARNKOWSKI, Admonitiones quinque circa sacramentorum administrationem faciendae, auctore [...] D. Stanislao Carcovio Episcopo Wladislaviensi, Coloniae 1572 apud M. Cholinum, w: S. Carncovius, Constitutiones in dioecesana synodo Wladislaviensi [...], Coloniae 1572 apud M. Cholinum.

${ }^{138}$ A. BRUŹDZIŃSKI, Wkład biskupa Stanisława Karnkowskiego..., s. 149.

${ }^{139}$ I. SUBERA, Synody prowincjonalne..., s. 108.
} 
obłożonym interdyktem, jawnym lichwiarzom, dopuszczającym się przemocy, winnym zabójstwa, bluźniercom i tym, którzy nie wykazali przed śmiercią żadnej skruchy za swoje grzechy. Proboszczowie byli zobowiązani do prowadzenia ksiąg zmarłych, aby w ten sposób oddalić jakiekolwiek oszustwa czy nadużycia, za które groził prawodawca karami bliżej nie określonymi. Na koniec prawodawca kierował do duszpasterzy zalecenie, aby troszczyli się o cmentarz, przypominając o obowiązku jego ogrodzenia i utrzymywania na nim należytego porządku ${ }^{140}$. O zakazie grzebania heretyków na cmentarzach zdecydowanie przypominał także synod z $1579 \mathrm{r}^{141}$

W nurt zagadnień mających wpływ na odnowienie duszpasterstwa miały również zarządzenia synodalne odnoszące się do postu. Jego szeroką i wnikliwą analizę teologiczną, jego praktyki i znaczenia w życiu chrześcijańskim podjął się biskup Karnkowski na synodzie w 1568 r. W artykule piątym zatytułowanym De Ieiuniis Ecclesiae, trzeciej części uchwał synodalnych, powołując się na uchwały soborowe $^{142}$, nakazywał, aby posty, które nałożył Kościół oraz te które wynikają z prawa zwyczajowego diecezji kujawsko-pomorskiej, były zachowywane w całej rozciągłości. Przypominał, że wierni po skończeniu 21 lat są zobowiązani pod karą grzechu ciężkiego do zachowania postu tak jakościowego, jak i ilościowego. Wzywał jednocześnie proboszczów do przypominania i pouczania wiernych o znaczeniu postu i obowiązku jego zachowywania oraz nie sprowadzaniu go do czystego rytualizmu ${ }^{143}$. Synod podawał jednocześnie wykaz postów, sprowadzając je do czterech okresów: całego Wielkiego Postu, wigilii świąt: Apostołów oprócz św. Filipa, Jakuba i Jana, przed Narodzeniem Pańskim, Zesłaniem Ducha Świętego, św. Jana Chrzciciela, Wawrzyńca, Wszystkich Świętych, Wniebowzięcia NMP oraz do święta

\footnotetext{
140 Tamże, s. 77-78.

${ }^{141}$ Secunda synodus dioecesana Stanislai Karnkowski, Wladislaviae Anno Domini 1579 celebrata, Z. CHODYŃsKi, Statuta synodalia..., s. 84.

${ }^{142}$ Conc. Trid., sess., XXV decr. de delectu ciborum.

${ }^{143}$ Acta synodi dioecesanae Wladislaviae anno 1568 per Stanislaum Karnkowski episcopum celebratae, Z. CHodý́sKi, Statuta synodalia..., s. 73-74.
} 
św. Marka i Dni Krzyżowe (cztery razy w roku po trzy dni) według prawa zwyczajowego istniejącego $\mathrm{w}$ diecezji. $\mathrm{W}$ te ostatnie synod zakazywał spożywania nawet jaj i mleka. Kończąc listę obowiązujących postów w diecezji biskup Karnkowski stwierdził stanowczo: „haec omnia in dioecesi nostra ubique observari volumus et mandamus" ${ }^{\text {"144. }}$. Ponadto przypominał o prawie proboszczów do dyspensowania od postu ludzi chorych, zastrzegając, „iż powinni oni wtedy modlić się więcej, większe składać jałmużny i spełniać dobre uczynki, o ile choroba im na to pozwala"145.

\section{Zakończenie}

Wielki i potrzebny dar reformy i odnowy duszpasterskiej ofiarowany Kościołowi połowy XVI wieku w uchwałach Soboru Trydenckiego został gorliwie i owocnie podjęty przez biskupa Stanisława Karnkowskiego i to $\mathrm{z}$ wielkim rozmachem na dwóch synodach diecezjalnych, odbytych w 1568 i 1579 r. Osadzone mocno w dekretach soborowych oraz statutach prowincjonalnych uchwały synodów normowały wiele sektorów życia duszpasterskiego ówczesnej diecezji kujawsko-pomorskiej, uaktywniając samych duszpasterzy, jak i angażując religijnie i moralnie wiernych świeckich. Ten wybitny ustawodawca, reformator, wyrosły i uformowany w atmosferze Tridentinum, zwolennik odnowy trydenckiej Kościoła i jego struktur duszpasterskich, zdawał sobie sprawę, że odnowa duszpasterstwa i naprawa życia religijno-moralnego musi znaleźć swój początek w reformie duchowieństwa, zachowaniu karności i dyscypliny kościelnej oraz w życiu i postępowaniu duchownych zgodnym z duchem powołania kapłańskiego.

Odnowie duszpasterstwa służyły też podejmowane wysiłki zmierzające do usprawnienia organizacji dekanatów oraz ożywienie działalności dziekanów, m.in. w zakresie kontroli duszpasterstwa, przypominania proboszczom ich powinności w zakresie poznawania parafian, opieki nad chorymi i ubogimi, zarządzenia odnoszące się

${ }^{144}$ Tamże.

145 Tamże, s. 74. 
do obrony wiary katolickiej zagrożonej reformacją, regulacje odnoszące się do nauczania prawd wiary, nauczania katechetycznego, sprawowania i przyjmowania sakramentów, kultu Bożego i spraw liturgicznych. To wszystko miało służyć posoborowej odnowie duszpasterstwa w Kościele włocławskim.

Swoje zaprogramowane działania uzdrawiające i reformujące duszpasterstwo w diecezji realizował nie tylko poprzez działalność synodalną, ale wspierał je poprzez wydane przez siebie Napomnienia oraz Admonitiones - agendę liturgiczną, które służyły ujednoliceniu liturgii i były pomocą dla duszpasterzy, nie tylko w diecezji kujawsko-pomorskiej. Analiza jego działalności ustawodawczej i duszpasterskiej upoważnia do stwierdzenia, że budował w diecezji nowe struktury życia religijnego, duszpasterskiego i kościelnego na bazie programu wytyczonego przez Sobór Trydencki. Stąd należał do najwybitniejszych biskupów polskich tamtego okresu. Zasłynął jako oddany reformator Kościoła katolickiego, obrońca wiary, krzewiciel oświaty, reformator obyczajów duchowieństwa i wiernych świeckich, a przede wszystkim jako wybitny i doświadczony prawnik ustawodawstwa synodalnego w Polsce oraz reformator duszpasterstwa.

\section{Pastoral renewal in Włocławek Diocese in the light of resolutions of Synod conventions of Bishop Stanisław Karnkowski from year 1568 and 1579}

Great and necessary gift of reform and pastoral renewal drawn up by Council of Trent was ardently and fruitfully taken up by Bishop Stanisław Karnkowski, and it was applied with great impact on two diocesan synods, which were held in 1568 and 1579. Synods' resolutions strongly embedded in council decrees and provincial statutes regulated many sectors of pastoral life of contemporary kujawsko-pomorska diocese, activating clergymen as well as engaging the secular faithful people religion-wise and moral-wise. This outstanding legislator, reformer, grown and formed in Tridentinum atmosphere, supporter of Trent's renewal of the Church and its priesthood structures, realized that renewal of priesthood and repair of religious-moral life has to find its beginning in the reform of clergy, keeping the church 
discipline as well as in the life and conduct of the clerical conformable with the spirits of vocation for the ministry.

Also the efforts aiming at better organization of deaneries served for renewal of priesthood as well as revival of deaneries' activity, amongst the other, within the range of priesthood control, reminding the rectors their duties within the range of getting to know their parishioners, taking care of the sick and poor people, dispositions referring to defending the catholic faith threatened by reformation, regulations referring to teaching the Truths of the Faith, catechistic teaching, performing and taking the sacraments, Gods' cult and liturgical issues. All of those was to serve post-council renewal of priesthood in Włocławek’s Church.

Bishop Stanisław Karnkowski realized his programmed actions curing and reforming the priesthood in dioceses not only by synodal activity, but also he supported them by Exhortations and Admonitiones issued by him liturgical agenda, which served unification of liturgy and were the help for clergymen, not only in kujawsko-pomorska diocese. Analysis of his legislative and ministry activity allows us to state, that he built in the diocese new structures of religious, priesthood and church life on the base of program laid out by Coucil of Trent. Hence he belonged to the most eminent Polish bishops of catholic Church, defender of the faith, promoter of education, reformer of habits and manner of the priest and secular faithful, and first of all as outstanding and experienced jurisprudent of synodal legislation in Poland and reformer of the priesthood.

SŁOWA KLUCzowe: Sobór Trydencki, reforma trydencka, diecezja włocławska, biskup Stanisław Karnkowski, synody biskupa Karnkowskiego.

Key Words: The Council of Trent, the Tridentine reform, Włocławek diocese, Bishop Stanislaw Karnkowski, synods Bishop Karnkowski.

\section{Nota o Autorze:}

KS. DR HAB. JANUSZ GRĘŹLIKOWSKI, PROF. UKSW - profesor nadzwyczajny na Wydziale Prawa Kanonicznego UKSW w Warszawie, kierownik katedry Historii Prawa Kanonicznego, Oficjał Sądu Biskupiego diecezji włocławskiej. 